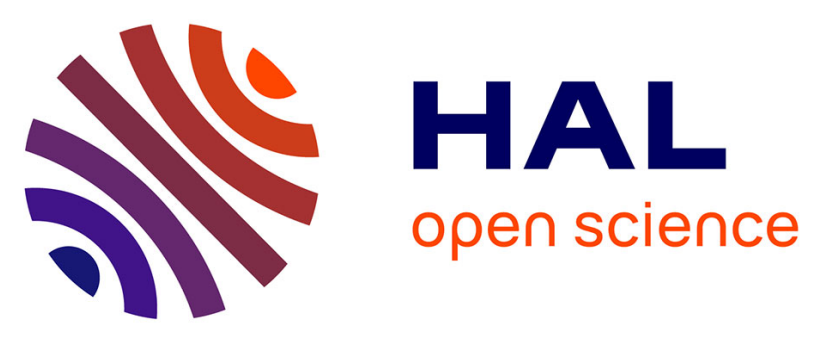

\title{
Planation surfaces of the Armorican Massif (western France): denudation chronology of a Mesozoic land surface twice exhumed in response to relative crustal movements between Iberia and Eurasia
}

Paul Bessin, François Guillocheau, Cécile Robin, Jean-Michel Schrötter, Hugues Bauer

\section{To cite this version:}

Paul Bessin, François Guillocheau, Cécile Robin, Jean-Michel Schrötter, Hugues Bauer. Planation surfaces of the Armorican Massif (western France): denudation chronology of a Mesozoic land surface twice exhumed in response to relative crustal movements between Iberia and Eurasia. Geomorphology, 2015, 233, pp.75-91. 10.1016/j.geomorph.2014.09.026 . insu-01116939

\section{HAL Id: insu-01116939 \\ https://hal-insu.archives-ouvertes.fr/insu-01116939}

Submitted on 16 Feb 2015

HAL is a multi-disciplinary open access archive for the deposit and dissemination of scientific research documents, whether they are published or not. The documents may come from teaching and research institutions in France or abroad, or from public or private research centers.
L'archive ouverte pluridisciplinaire HAL, est destinée au dépôt et à la diffusion de documents scientifiques de niveau recherche, publiés ou non, émanant des établissements d'enseignement et de recherche français ou étrangers, des laboratoires publics ou privés. 
Title: Planation surfaces of the Armorican Massif (western France): denudation chronology of a Mesozoic land surface twice exhumed in response to relative crustal movements between Iberia and Eurasia

\section{Author names and affiliations:}

\section{Paul BESSIN ${ }^{\mathrm{a}}$}

a: Géosciences Rennes, UMR 6118, Université de Rennes 1, CNRS 263, avenue du Général Leclerc, 35042 Rennes cedex, France; paul.bessin@univ-rennes1.fr, paul.bessin@gmail.com

\section{François GUILLOCHEAU ${ }^{\mathrm{a}}$}

a: Géosciences Rennes, UMR 6118, Université de Rennes 1, CNRS 263, avenue du Général Leclerc, 35042 Rennes cedex, France

\section{Cécile ROBIN ${ }^{\mathrm{a}}$}

a: Géosciences Rennes, UMR 6118, Université de Rennes 1, CNRS 263, avenue du Général Leclerc, 35042 Rennes cedex, France

\section{Jean-Michel SCHROËTTER ${ }^{b}$}

b: BRGM, Direction régionale Bretagne, Rennes Atalante Beaulieu, 2 rue de Jouanet, 35700 Rennes

\section{Hugues BAUER ${ }^{c}$}

': BRGM, Centre scientifique et technique, 3 avenue Claude-Guillemin, BP 360009, 45060 Orléans cedex 02, France

\section{Corresponding author:}

\section{Paul BESSIN}

a: Géosciences Rennes, UMR 6118, Université de Rennes 1, CNRS, 263 avenue du Général Leclerc, 35042 Rennes cedex, France;

email: paul.bessin@univ-rennes1.fr,paul.bessin@gmail.com

telephone: +332 23236429 


\section{Abstract}

The Armorican Massif, an extensive outcrop of Variscan basement in western France, is shaped by several planation surfaces of debated origin and age. We propose an evolution model for these landforms and their deformation based on detailed mapping of the planation surfaces, their relative chronology and their relationships with dated outcrops of sediments and weathering products. The Armorican landscape consists of six stepped planation surfaces (labelled PS1 to PS6) later incised by two successive river networks. These landforms are pediments and pediplains or polygenic landforms (Armorican Planation Surface - PS5) resulting from two periods of etchplanation. These planation surfaces are mostly pre-Late Cretaceous in age, based on the age of the sediments overlapping these pediments. The three older ones (PS1 to PS3) are pre-Pliensbachian (191-183 Ma); PS4 is preBajocian (170-168 Ma), PS5 (here called the "Armorican planation surface") is polygenic and ranges from the base of the Early Cretaceous to the base of the Bartonian (140-40 Ma); and the youngest (PS6), which is poorly constrained, is older than $40 \mathrm{Ma}$ (base of the Bartonian) or $15 \mathrm{Ma}$ (base of the Middle Miocene). Most of these "old" landforms are exhumed, i.e. they were buried by sediments and later re-exposed by denudation. At least two phases of burial and exhumation have been identified: (1) burial in Jurassic time followed by denudation during the early Cretaceous and (2) burial in late Cretaceous time followed by denudation during the latest Cretaceous to early Eocene. The depth of burial is unknown but is probably low due to the small amount of coeval siliciclastic sediments in the surrounding basins. The two periods of exhumation correspond to critical periods in the plate movements between Africa, Iberia and Eurasia. The first is probably related to the initiation and breakup of the rift between Iberia and Eurasia and the second to the convergence between these two plates.

Keywords: Armorican Massif; exhumation; planation surface; pediment; Mesozoic; Cenozoic 


\section{Introduction}

The geology of north-western Europe is a complex pattern of sedimentary basins (North Sea, Western Approaches, London and Paris basins, etc.) and outcrops of Proterozoic to Paleozoic basement (Cornwall, Armorican Massif, Ardennes-Eifel, Vosges-Black Forest, French Massif Central, etc.).

The relief of these basement outcrops has been extensively shaped into a succession of planation surfaces. These nearly flat topographic surfaces range from $\times 10 \mathrm{~km}^{2}$ to $\times 1000 \mathrm{~km}^{2}$ and bevel the underlying bedrock structures despite residual hills (Brown, 1968; Migoń, 2004a; Huggett, 2011). Although their relative spatial extent and age are still debated (Widdowson, 1997), several types of planation surfaces have been described in Europe:

(1) peneplains (British Isles: Wooldridge and Linton, 1955; Brunsden, 1963; Scandinavia: Elvhage and Lidmar-Bergström, 1987; Lidmar-Bergström, 1989; 1995; 1999; LidmarBergström et al., 1997; Johansson et al., 2001).

(2) pediplains and pediments (Hungary: Pécsi, 1970; Pinczés, 1970 - Germany: Rosenkranz, 1970 - British Isles: Dury, 1972 - Scandinavia: Lidmar-Bergström, 1995; Lidmar-Bergström et al., 1997; Johansson et al., 2001).

(3) etchplains, which are either mantled (Sudetes: Migoń, 1997; 1999 - Western Europe: Migoń and Lidmar-Bergström, 2001) or stripped (British Isles: Jones, 1999 - Scandinavia: Lidmar-Bergström, 1999; Johansson et al., 2001 - Western Europe: Migoń and LidmarBergström, 2001).

(4) wave-cut platforms (British Isles: Ramsay, 1846; Wooldridge and Linton, 1955; Brunsden, 1963).

Planation surfaces in the Armorican Massif, have been mapped by de Martonne (1906), Musset (1922), Guilcher (1948; 1949) and Klein (1975). In these classic studies, most authors agreed on the existence of several planation surfaces with ages ranging from the Mesozoic for the most elevated, to the Cenozoic for the closest to sea-level. Some scholars have also discussed the nature of the planation surfaces: Meynier $(1951,1952)$, Klein $(1975,1990)$, Sellier (1985) and Wyns (1991) suggested that many surfaces were pediments, but based on the occurrence of rounded pebbles at some locations, Klein (1975) also advocated wave-cut platforms. At the same time, numerous 
occurrences of deep weathering products such as laterites and silcretes were described by a number of geologists (Ferronnière, 1921; Kerforne, 1921; Milon, 1932; see Estéoule-Choux, 1983 for a review). These weathering mantles suggest that some Armorican landforms were shaped in a different climatic setting (hot semi-arid or hot and very humid) from the present, as suggested long ago by Jessen (1938) for Germany. The present-day network of valleys has incised these planation surfaces. Fluvial incision started at the transition between the early and middle Pleistocene. The timing is related to the Africa/Apulia/Eurasia convergence regime and was enhanced by major early to middle Pleistocene climate change (Bonnet et al., 2000).

The aim of this paper is (1) to characterize the different types of pre-incision landforms (incised valleys were previously studied by Bonnet, 1997 and Bonnet et al., 2000), their relative chronology, their links with dated sediments and weathering mantles and (2) to propose a model of evolution for these landforms at the scale of the entire Armorican Massif.

\section{Regional setting}

\subsection{Geology}

The Armorican Massif is a Variscan (Hercynian) basement (late Devonian to Carboniferous deformations) with some remnants of Cadomian (late Neoproterozoic) deformations (Chantraine et al., 2001; Ballèvre et al., 2009). This basement outcrop is surrounded by three main sedimentary basins: the Western Approaches Basin to the north, the Armorican and Celtic Margins to the west and south, and the Paris Basin to the east.

The Armorican Massif is made up of three main Variscan units (Ballèvre et al., 2009) bounded by major N110E shear faults: the North Armorican Shear Zone (NASZ) and the two branches of the South Armorican Shear Zone (SASZ). The basement consists of metamorphic rocks (micaschist and gneiss, dominant south of the SASZ), sedimentary rocks (schist, sandstone and quartzite, dominant between the NASZ and the SASZ), and plutonic rocks (granites are widespread). The bedrock was densely fractured by N140E faults at the time of the Permian-Triassic extension (aborted pre-Atlantic rifting episode; Ziegler, 1990). 
The Western Approaches Basin is a long-lived, complex depocentre (Ziegler, 1987; Ruffell, 1995). It was initiated at the time of the Permian extension (rift 1), reactivated during the early Cretaceous North-Atlantic extension (rift 2), and inverted during late Paleogene times (Le Roy et al., 2011).

The Paris Basin (Perrodon and Zabek, 1990; Guillocheau et al., 2000) is an intracratonic basin floored by Lower Triassic strata. It underwent moderate inversions during early Cretaceous time and buckled under a compressive stress regime during Cenozoic times.

The Armorican and Celtic continental margins were initiated at the time of the first oceanic accretion in the Bay of Biscay, i.e. during the uppermost Aptian (early Cretaceous) (Montadert et al., 1979; Thinon et al., 2003). The Armorican passive margin is a starved continental margin, whereas the Celtic margin has been more abundantly supplied with sediment by the (English) Channel since the Neogene (Bourillet et al., 2003).

These basins were controlled by plate movements between Iberia (Africa) and Eurasia at the time of early rifting in the North Atlantic and Bay of Biscay (early Cretaceous) and later during the peak of Pyrenees compression (latest Cretaceous to Eocene, see Vissers and Meijer, 2012a; 2012b for a review).

Detailed Jurassic and Cretaceous palaeogeographic maps (Enay et al., 1980; Hancock and Rawson, 1992; Lasseur, 2007) indicate (1) that facies lines can be traced across the modern boundaries of the Armorican Massif, meaning that the present-day limits of the basins are erosional; and (2) that the Armorican Massif was partly (or totally) covered by sediments.

\subsection{Geomorphology and landscape evolution since the Mesozoic}

The present-day topography of the Armorican Massif is structured around three main upland areas: the Western Brittany Plateau, the Vendée High and the Lower Normandy Plateau (Fig. 1). The mean elevation of the study area is 150 to $220 \mathrm{~m}$, the highest summit is $417 \mathrm{~m}$, and low areas (Eastern Brittany Low, Ligerian Low and Maine Low) range between $30 \mathrm{~m}$ and $100 \mathrm{~m}$. The SASZ is an important structure to the south and defines the boundary with a low-lying flat domain hereafter called the Vannes Platform (Fig. 1). All of these physiographic units are incised by rivers to various depths. 
De Martonne (1906) was the first to recognize a planation surface (defined as a peneplain) of regional importance, extending everywhere around the Western Brittany Plateau and deformed after its planation. Musset $(1917 ; 1922 ; 1928)$ identified two other deformed planation surfaces, both more elevated than the one described by de Martonne. Meynier (1940), Gautier (1947), Guilcher (1948; 1949), and Klein (1975) argued for a pre-Eocene age for de Martonne's regional lower planation surface based on the occurrence of dated Eocene silicified deposits in the eastern part of the Armorican Massif, and ascribed a Mesozoic age to the two upper surfaces.

Some scattered vestiges of Mesozoic and Cenozoic sediments are preserved on the weathered basement of the Armorican Massif. The oldest sediments, of early (PliensbachianToarcian) and middle (Bajocian-Bathonian) Jurassic age, occur on the Lower Normandy Plateau (Rioult, 1968; Dugué, 2007). Remnants of Upper Cretaceous marine sediments are more widely distributed (Durand et al., 1973; Juignet, 1974; see compilation below). After a period of lateritic weathering, attested by kaolinite reworking in various Eocene deposits (Estéoule-Choux and OllivierPierre, 1973; Ollivier-Pierre, 1980), the Armorican Massif was flooded at least six times by rising sealevels (Guillocheau et al., 2003) during (1) the early Eocene (Ypresian), along the southern part of the Armorican Massif, (2) the base of the late Eocene (Bartonian), (3) the early Oligocene (Rupelian), (4) the middle Miocene, (5) the uppermost Miocene (Messinian?) and the early Pleistocene (Gelasian). Between the Bartonian and Rupelian sea-level rises, lacustrine aggradation occurred, preserved in N150E grabens (Rennes, Landéan, Saffré) mostly located in the Eastern Brittany Low. The middle Miocene flood and associated marine bioclastic limestones (mainly located along the Carentan Flat, the Eastern Brittany Low and the Lower Loire Platform: Durand, 1959; Lécuyer et al., 1996; Courville and Bongrain, 2003; Dugué et al., 2005) are clearly of eustatic origin. The basement and these previous deposits were later incised by (1) a first drainage network during the late Miocene, forming valleys that became later filled by the continental to estuarine Upper Miocene to Pliocene "Red Sands" (Brault et al., 2004; Dugué et al., 2007); and (2) a second generation of rivers, which form the modern drainage and were emplaced around the early to middle Pleistocene boundary (Bonnet et al., 2000).

\subsection{Palaeoclimate}


The world-scale Cenozoic temperature curve has been quite well known since the works of Miller (Miller et al., 1977) and Zachos (Zachos et al., 2001; 2008). The cool latest Cretaceous was followed by global warming during the early Eocene and then by overall cooling since the EoceneOligocene transition. The palaeoprecipitation curve, however, which is key to the interpretation of past landforms, is poorly known. The only available constraints are palaeobotanical data (mainly pollens and spores) and palaeosols. At the European scale, the Middle Jurassic was very hot and humid, evolving to drier conditions at the Jurassic-Cretaceous boundary. The early Cretaceous was again very humid, with the formation of lateritic profiles (Lower Cretaceous laterites - Ardennes: Yans, 2003; French Massif Central: Théveniaut et al., 2007; Ricordel-Prognon et al., 2010). Cenozoic Armorican deposits record tropical humid (Paleocene to early Eocene) to semi-arid (late Eocene to Oligocene) conditions (Durand and Ollivier-Pierre, 1969; Châteauneuf, 1980; Ollivier-Pierre, 1980; Ollivier-Pierre et al., 1987) until the Miocene-Pliocene boundary, a period during which the presentday climatic conditions prevailed across Europe (Mosbrugger et al., 2005; Roche et al., 2008; Utescher et al., 2009).

\section{Material and methods}

This study is based on planation surface mapping in the Armorican Massif and aims to establish the relative chronology, age and formative processes of the different generations of land surfaces identified. After completion, a planation surface can be (1) tilted or updomed on a wavelength of at least $\times 10 \mathrm{~km}$, and/or (2) bevelled in response to a local fall in base level, resulting in two surfaces with the older step occurring at a higher elevation and the younger at a lower elevation. Given that a planation surface can be deformed by crustal movements, it follows that its elevation can vary across the regional landscape. An erosion surface can also be shaped by different erosional processes due to relative base-level changes and thus become a polygenetic surface (Peulvast and Claudino Sales, 2005), i.e. a surface shaped by more than one deformation event or one climatic regime.

The characterization and relative chronology of these planation surfaces was obtained by combining Digital Elevation Model (DEM) analysis (IGN, 2011; Jarvis et al., 2008) under ArcGIS 10@ with field controls. The characterization and mapping (at the scale of $1: 80,000$ ) of the planation surfaces are based on a combination of three different GIS analysis methods: 
1- 3D visualization of the DEM (using ArcScene ${ }^{\mathrm{TM}}$ ) with a vertical exaggeration of $\mathrm{x} 15$, in order to emphasize the continuity of the inclined planation surfaces (primary or tilted by deformation) at a local scale, which is one of the limits of the approach but provides an innovation over the previous classic monographs dealing with the region (e.g. Klein, 1975).

2- Slope, shading and curvature analysis from the DEM (Smith and Pain, 2011), which are effective techniques for mapping the dissection of planation surfaces by valley networks as well as the contours of scarps forming the upper boundaries of planation surfaces.

3- Landform classifications from the DEM analysis performed in a Geographical Information System (GIS). Several classification methods were tested such as the Hammond (1964) landform typology, later automated (Dikau et al., 1991; Morgan and Lesh, 2005), which is based on a combination of slope, local relief and curvature parameters for a chosen number of neighbourhood cells. However, the Topographic Position Index (TPI) Landform Classification (Weiss, 2001; De Reu et al., 2013) has lately been preferred due to an empirical best fit with observed landforms. This method is based on the measurement of the TPI (difference between the elevation of a cell and the elevation of cells in a given neighbourhood radius) classified into discrete slope-position classes using the TPI standard deviation and slope values to identify ridges, upper slopes, middle slopes, flats, lower slopes and valleys. The parameters from two neighbourhood radii (best fits used in this study: $500 \mathrm{~m} / 2000 \mathrm{~m}$; $1000 \mathrm{~m} / 4000 \mathrm{~m}$ ) are combined to produce the final classification in order to reveal more complex landscape information. The TPI Landform Classification combined with previous methods (3D visualization and classical DEM analysis) provides great accuracy when mapping planation surfaces, scarps and incised valleys.

The relative chronology and dating of the planation surfaces were based on the geometric relationships between these surfaces and sediments and weathering mantles of known age. To date these surfaces, a GIS mapping project was elaborated using (1) different landform maps published since 1950; (2) geological maps of France at 1:50,000 scale (source data provided by the Bureau des Recherches Géologiques et Minières) for lithology, weathering mantles and Mesozoic to Cenozoic sedimentary rocks; and (3) dated outcrops (mainly Cenozoic sediments) culled from the literature. Numerous topographic profiles were drawn from the DEM (see sections 4.4 and 4.5 ) at two scales, i.e. for each plateau or high and for the whole Armorican Massif, each time integrating all of the 
aforementioned information layers. Most of the ages provided by fossils (biostratigraphy) were reevaluated and are reported in the current international stratigraphic chart (ISC 13) reference frame.

\section{Armorican landforms}

\subsection{The Lower Normandy Plateau showcase}

Most landforms of the Lower Normandy plateau show uniform morphological characteristics which can be summarized as follows (see Fig. 2):

(1) The land surface exhibits flat or gentle gradients (minimum: 0.01\%; maximum: $2 \%$; mean: $0.5 \%)$, with concave-up profiles that sharply truncate the underlying heterogeneous bedrock (Figs. 2A, 2B and 2C, underlined in red). These surfaces are $10 \mathrm{~km}$ in width (minimum: $3 \mathrm{~km}$, maximum: $8.5 \mathrm{~km}$ ) and x10 km long (minimum: $11 \mathrm{~km}$, maximum: $29 \mathrm{~km}$ ). These land surfaces cover areas ranging from $26 \mathrm{~km}^{2}$ (Fig. 2B) to $195 \mathrm{~km}^{2}$ (Fig. 2C) i.e. $\times 10 \mathrm{~km}^{2}$ to $\times 100$ $\mathrm{km}^{2}$ in magnitude. In addition, these surfaces are slightly dissected by the present-day river network. The incisions are underlined by $0.3 \mathrm{~km}$ to $3.4 \mathrm{~km}$ wide and $8 \mathrm{~m}$ to $70 \mathrm{~m}$ deep valleys with depth/width ratios ranging from 12 to 136 .

(2) The flat or dipping surfaces are bounded by steeper slopes from around $6 \%\left(3.4^{\circ}\right)$ to scarps with slopes of $25 \%\left(14^{\circ}\right)$, which separate these surfaces from the older and higher planation surfaces (landform boundaries outlined in red in Fig. 2, 3D views). These steeper slopes or scarps are, in map view, continuous, straight or slightly sinuous and are not dissected by an incised channel network coeval with the lower flat surface to which they (steeper slopes or scarps) are linked. The flat surfaces bounded by the steeper slopes/scarps define large flatbottomed valleys into which the incised Pleistocene valley network cuts randomly. These incised valleys are found to either, (1) flow across rather than along the flat surfaces, (2) be superimposed only on the downstream part of the gently dipping surfaces, or (3) be incised into upslope part rather than into the downslope part of the surfaces. This suggests that the incised river network bears no connection with the formation of the flat to gently dipping surfaces, i.e. the incised valleys are young and were superimposed onto these low-gradient landforms. 
(3) No alluvial sediments (alluvial fans, low preservation fluvial channels) are preserved on these surfaces, but the Lower to Middle Jurassic marine sediments fossilized these landforms (pediment in Fig. 2B: flooded by Middle Jurassic open marine shallow carbonates which onlap Paleozoic quartzites, Doré et al., 1977; Fily, 1989; Gigot et al., 1999; Dugué, 2007; pediment in Fig. 2C: coastal Lower Jurassic deposits, Rioult, 1968; Kuntz et al., 1989; Dugué, 2007). These sediments fill, flood and fossilize the flat to gently dipping surface, shown here by sketches in Figure 2.B'.

These characteristics fit the definition of a specific type of planation surface, namely pediments, which involve (Whitaker, 1979; Dohrenwend and Parsons, 2009):

- a nearly flat erosional surface (Brown, 1968; Whitaker, 1979; White, 2004) truncating a heterogeneous mosaic of rock outcrops;

- an upslope scarp connecting with upstanding landforms (Cooke, 1970; Dohrenwend and Parsons, 2009);

- no cogenetic river channels (whether erosional or depositional) - only shallow-incision migrating streams ( $\mathrm{x} 1 \mathrm{~m}$ deep, $\mathrm{x} 0.1$ to $\mathrm{x} 1 \mathrm{~km}$ wide: Strudley et al., 2006; Dohrenwend and Parsons, 2009);

- concave-up longitudinal profiles (Tator, 1952; 1953; Brown, 1968).

Pediments had been previously recognized by researchers across the Lower Normandy Plateau (Klein, 1975, 1990) or across the western and southern parts of the Armorican Massif (Meynier, 1951; 1952; Sellier, 1985; Wyns, 1991), although in a less systematic way than allowed here by GIS analysis. Some pediments are controlled by lithology, mainly by quartzite of Paleozoic age (Early Ordovician Armorican Quarzite, Late Ordovician and base Devonian quarztitic sandstones of the Western Brittany and Lower Normandy plateaus). Elsewhere in the Armorican Massif, other lithological contrasts, such as between metamorphic and plutonic rocks, do not control the location of the first-order planar landscape units such as the Léon-Trégor and Vannes Platform areas.

\subsection{Planation surfaces in other parts of the Armorican Massif}

The Western Brittany Plateau displays planation surfaces with similar characteristics to the Lower Normandy Plateau, i.e. pediments. North of the Loire River, a large and nearly flat surface 
extends from the Léon-Trégor Platform (W) to the Eastern Brittany Low (E) and to the Vannes Platform (S), between and around the Lower Normandy and Western Brittany Plateaus. This surface, hereafter called the Armorican Surface, is large: it covers an area of approximately $25,000 \mathrm{~km}^{2}$, and is bounded by scarps or steeper slopes around its upper rim. This Armorican Surface answers to the definition of a pediplain, i.e. a planation surface made up of coalescent pediments (King, 1953). Locally (Léon and Vannes Platforms), the Armorican Surface is covered by undated conglomerate beds containing rounded pebbles of possible marine origin, cropping out at an elevation between 130 m and 210 m (Bourcart et al., 1950; Guilcher and Saint-Réquier, 1969; Hallégouët, 1972; 1976; Plusquellec et al., 1999). This feature suggests that parts of the Armorican Surface might have been shaped by marine wave processes and evolved as a wave-cut platform.

\subsection{Planation surfaces and weathering mantles}

As shown by a compilation (Fig. 3 ) of the most recent 1:50,000 scale geological maps of France, where "surficial" formations (soft rock outcrops sometimes up to 30-50 m deep) have been mapped, most of the basement rocks of the Armorican Massif are weathered. Three types of weathering mantle have been characterized in the study area.

(1) Laterites. Complete lateritic profiles in tropical regions can exhibit a thick saprolite (approximately $40 \mathrm{~m}$, maximum $90 \mathrm{~m}$ ) capped by an iron duricrust. Such occurrences are well preserved in the Eastern Brittany Low and on the low-elevation planation surfaces of the Western Brittany Plateau (see Estéoule-Choux, 1983 for a review). Most of these profiles have been stripped so that only the lower part of the saprolite is preserved: in the field, they appear as kaolinized schist/micaschist, feldspar-rich granite or gneiss.

(2) Grus. These weathered layers occur mainly on feldspar-poor granite. Most researchers have agreed in the past that grus forms under temperate weathering conditions (e.g. Lageat, 2014). Recent drillholes and geophysical investigations for water resources in the grus-dominated areas (Wyns et al., 2003; Lachassagne et al., 2011) indicate instead (i) thicker deposits than expected (40-85 m) and (ii) a location of the grus at the base of large lateritic profiles. For these authors, grus is thus none other than the weathering front of stripped lateritic profiles. 
(3) Silcretes. Presumed silcretes were identified over most of the Armorican Massif. Nevertheless, the use of this term is confusing because most of the silicified sandstones have been labelled as silcrete (Estéoule-Choux, 1983). The two varieties of silicified sandstones recognised by Thiry $(1988 ; 1997)$ and Thiry et al. $(1988 a ; 1988 b)$ in the Paris Basin have been found in the Armorican Massif: (1) true silcretes involving illuviation structures overprinted on alluvial deposits, and (2) groundwater silicifications of alluvial sediments.

All these weathering materials cover the different pediment or pediplain levels. True lateritictype weathering profiles (type (1) with kaolinite; not type (2), which is more debatable) are widely distributed. This implies that the pediments and pediplains are older than the silcretes and that they are older than or coeval with the laterites (Fig. 3). These weathered planation surfaces might be stripped etchplains by virtue of pedimentation processes. Two main types of etchplain have been defined in the literature (Migoń, 2004b): (1) mantled etchplains, which correspond to flat weathering surfaces by laterites (Millot, 1980) and (2) stripped etchplains, which are mantled etchplains dissected by rivers or retouched by pedimentation (Büdel, 1957; Thomas, 1989a, 1989b; Bremer, 1993; Twidale and Bourne, 2013).

Some of these planation surfaces, e.g. the Armorican Surface, are polygenetic surfaces with evidence of weathering (etchplanation?), coalescent pediments (collectively forming pediplains) and local reworking by waves (wave-cut platforms).

\subsection{Relative chronology of the planation surfaces}

At least six stepped planation surfaces, bounded by steeper slopes or scarps but not faults, were mapped (Figs. 4 and 5) at the scale of the Armorican Massif, north of the Loire River. The major planation surface, hereafter called the Armorican Planation Surface (PS5, Figs. 4 and 5), extends from western Brittany to the Paris Basin. This surface is physically continuous over the entire Armorican Massif, meaning that this surface can be traced and mapped, with no main break in slope. Consequently, this surface is not flat and occurs at different elevations (minimum: $30 \mathrm{~m}$, maximum: $110 \mathrm{~m})$. At any given location, specimens of the Armorican Planation Surface occur one step down from the two major plateaus (Western Brittany and Lower Normandy) and are bounded by scarps or by steeper slopes that are traceable in the upslope region of the pediments. Below this major surface, 
only one generation of pediments has been detected (labelled PS6, Fig. 6). PS6 is itself incised by the present-day valley network. The Armorican Surface can be dissected and degraded by these youngest pediments and valleys, and has been accordingly mapped as PS5d (for "degraded").

For planation surfaces older than the PS5, a relative chronology was established for both plateaus. On the Lower Normandy plateau (PS1 to PS4, Fig. 4), at least four generations of pediments can be mapped below some residual hills. A certain amount of reactivation of the basement faults (Mayenne and Merlerault Faults, SASZ) has locally disrupted this leitmotiv. On the Western Brittany Plateau, which is geographically isolated from the Lower Normandy Plateau, the same number of stepped pediments has been identified.

4.5 Dating the planation surfaces: towards an age model

On the Lower Normandy Plateau, pediments PS1 and PS2 (Fig. 4) are sealed by Aalenian to Bathonian silicified marine oolithic limestones (Doré et al., 1977; Kuntz et al., 1989) and specimens of pediment population PS3 (Fig. 4) are sealed by Pliensbachian transgressive sandstones and claystones (Kuntz et al., 1989). Overlapping of the youngest pediment by the older sediments implies a pre-Pliensbachian age for the pediment generations labelled PS1 to PS3 (Fig. 4).

Specimens of pediment PS4 (Fig. 4) are flooded by Bajocian shallow marine carbonates (Kuntz et al., 1989) lapping onto the pediment scarp ("Ecueils", Ménillet et al., 1994, 1997; Peulvast and Claudino Sales, 2005).

The Armorican Surface (PS5), is covered by late Cretaceous (Cenomanian to Campanian) deposits (Figs. 4 and 6). These occur in various forms (see Fig. 6 caption for references), including (1) thin fossiliferous claystones at the base of transgressive siliciclastic deposits, (2) marine carbonates (chalk) preserved in situ, (3) marine sediments collapsed into karstic cavities, (4) chalk flints or silicified late Cretaceous fossils preserved as undissolved components of a weathering profile (Claywith-Flints) or (5) reworked late Cretaceous clasts at the base of younger Cenozoic sediment (Bartonian to Pliocene - reworking of the microfossils) or in Pleistocene coastal deposits (PreHolocene - flints and chalk). Weathered surface PS5 is also covered by (1) Eocene to Oligocene sediments (La Trinité-Porhoët, Saffré, Céaucé, Rennes among other locations, see Durand, 1959; Estéoule-Choux, 1970; Ollivier-Pierre, 1980; Ollivier-Pierre et al., 1988 for reviews), (2) complete 
lateritic profiles (Estéoule-Choux, 1983), (3) numerous silcretes (see Brault, 2002 for a compilation), and (4) undated conglomerates (sometimes intensely ferruginised) with rounded pebbles of possible marine origin, cropping out at elevations between $150 \mathrm{~m}$ and $210 \mathrm{~m}$ (Bourcart et al., 1950; Guilcher and Saint-Réquier, 1969; Hallégouët, 1972; 1976; Plusquellec et al., 1999). The Cretaceous sediments are mainly marine, whereas the Eocene to Oligocene deposits are mostly continental. This means that the first planation of surface PS5 occurred after the middle Jurassic (age of the PS4 pediments) and before the late Cretaceous.

Pediments PS6 bear some late Eocene to early Oligocene sediments. However, because these deposits are preserved in grabens (e.g. Ollivier-Pierre et al., 1988; 1993) and the timing of the fault is still being discussed (syn- or post-depositional, Guillocheau et al., 2003), they cannot provide a precise constraint on the age of PS6.

Silcretes can be found capping landforms from PS3 to PS6. Some of them contain leaves of Sabalites andegavensis (over PS5) that have been dated as Eocene (Ypresian-Bartonian) in the surroundings of Le Mans (Crié, 1878) and in Brittany (Durand, 1959; Estéoule-Choux, 1970; see Klein, 1975 for a review). The evidence has been confirmed by pollen studies (Châteauneuf, 1980; Juignet et al., 1984).

The remaining question is the age of the planation surfaces of the Western Brittany Plateau. Due to the absence of dated sediments, the only argument currently available is the analogy with the Lower Normandy Plateau, which displays the same number of terraced pediment levels.

Planation surface extent and age (preserved and degraded) are summarized in Figure 5 . This document also provides information about land surface deformation by major faults. For example, the SASZ divides the Armorican Surface (PS6) into two domains, the Vannes Platform (southward) and the Eastern Brittany Low (northward), with different elevations but with the same weathering materials and stratigraphic age brackets. Similar patterns were encountered on either side of the Domfront and Mayenne Faults.

\section{Discussion}

5.1. The Armorican Massif: an exhumed land surface 
Our results suggest Mesozoic ages for most of the planation surfaces of the Armorican Massif (PS1 to PS4, main planation of polygenetic PS5), and thus great antiquity of the land surface. Ancient landforms on other continents have been discussed (e.g. in Australia, Twidale, 1997) but it is often argued that preservation is only possible in cases where the topography was buried by younger sedimentary rocks and later exhumed (e.g. Lidmar-Bergström et al., 2013). Here, some of the tell-tale cover rocks have been preserved as discrete outcrop patches (Figs. 4 and 6) and provide age brackets to two main periods of burial: (1) the early to middle Jurassic (for planation surfaces PS1 to PS4) and (2) the late Cretaceous (for the Armorican Surface - PS5).

The accumulation of Jurassic and Upper Cretaceous marine sediments on the Armorican Massif is in agreement with the palaeogeographic reconstructions proposed from studies of the sedimentary basins. Since the Bathonian, the most authoritative compilation provided by the French Jurassic Research Group (Enay et al., 1980) shows evidence of marine deepening toward the present-day eastern border of the Armorican Massif (i.e. the western edge of the Paris Basin), suggesting marine flooding of this part of the Armorican Massif during the middle Jurassic and part of the late Jurassic. Similarly, along the NW side of the massif, in the Western Approaches Basin, industrial wells show open marine conditions $50 \mathrm{~km}$ WNW of Ushant Island (well Lizenn 1) for most of the Jurassic (except the Tithonian). Palaeogeographic maps of the Paris Basin (Lasseur, 2007) and of the Western Approaches (Hancock and Rawson, 1992), and industrial wells along the southern Armorican margin (Penma 1, in Paquet et al., 2010) and in the Western Approaches (Ruffell, 1995) suggest major deepening of these basins during the Campanian peak of chalk deposition (presence of ocean-floor current deposits occurring between the Proto-Atlantic and the Tethys oceans; Esmerode and Surlyk, 2009), followed by a relative sea-level rise that flooded the Armorican Massif.

The denudation periods can be deduced from the siliciclastic sediment inputs into the surrounding basins. This occurred twice after the Jurassic period of deposition, namely during the early Cretaceous (Wealden Group: Berriasian to Barremian, and Lower Greensand Group: Aptian to early Albian facies) and the early Cenozoic (mainly Ypresian). It follows that sedimentation occurred before (Jurassic) or in between (late Cretaceous chalk) these two episodes of clastic input. Denudation of the Armorican Massif thus occurred in two stages, first during the early Cretaceous and subsequently during the early Cenozoic. 
This scenario fits with the record of two periods of weathering during the early Cretaceous and earliest Cenozoic. Lateritic profiles preserved below onlapping Cenomanian sediments on the Paris Basin side of the Armorican Massif (Rioult et al., 1966; Steinberg, 1967; Estéoule-Choux et al., 1969; Vérague, 1974; Wyns et al., 2003) indicate a first Cretaceous period of laterite formation, confirmed by palaeomagnetic dating of lateritic duricrusts on the north side of the French Massif Central (Ricordel, 2007; Théveniaut in Quesnel et al., 2009a; Ricordel-Prognon et al., 2010). The second period of laterization peaked during the early Cenozoic (red beds, or "siderolithic" facies, Estéoule-Choux, 1983). The warm climate that promoted the formation of these laterites probably also explains the deep chemical denudation of Jurassic and late Cretaceous carbonate platforms that buried and preserved these ancient land surfaces.

These elements indicate that the Armorican relief is mostly an exhumed landscape. Exhumation occurred on at least three successive occasions (during the Triassic, i.e. the terminal planation of the Variscan orogenic belt; the early Cretaceous; and the Cenozoic), and was interrupted by two periods of burial (the Jurassic and the late Cretaceous).

Other exhumed landforms and land surfaces have been reported in continental Europe. In Poland, the Sudetic landforms were buried under Neogene sedimentary sequences (Migoń, 1999). In Sweden, Lidmar-Bergström (1996) described a similar setting to the Armorican Massif with old relief buried by Jurassic and Cretaceous cover rocks. Based on the currently estimated extent of late Cretaceous marine flooding and the widespread distribution of open marine chalk, other basement massifs (e.g. the Ardennes) could also have become partly exhumed after the late Cretaceous (see section 5.5).

\subsection{Depths of denudation and burial of the exhumed topography}

The preservation of old (Mesozoic) landforms and patches of Jurassic and Cretaceous sediments (Figs. 4 and 6) implies that total denudation depths have been low. Few thermochronological data are available for the Armorican Massif (Siddall, 1993). Siddall studied apatite fission-track samples located along the coast from the eastern Lower Normandy Plateau to Vendée. The fission-track ages record three peaks at 150-160 Ma, 190-200 Ma and 210-230 Ma. Fully published data are not available and the reliability of these results is debatable. However, these 
late Triassic to Jurassic ages mean that the amount of post-Jurassic denudation is quite low. The amount of denudation can also be discussed from the volumes of siliciclastic sediments supplied during the early Cretaceous and Cenozoic and currently preserved in the surrounding basins.

The most important period of erosion was the early Cretaceous, with the influx of the Wealden Group siliciclastic deposits all around the Armorican Massif. In the Bay of Biscay and the Western Approaches, these sequences filled rifts (Ziegler, 1987; Ruffell, 1995; Thinon et al., 2001), mainly supplied by the local topographic highs, i.e. the rift shoulders. In the intracratonic Paris Basin, the maximum thickness of early Cretaceous siliciclastic sediments is $500 \mathrm{~m}$ (deposited over a period of 45 Ma), which is rather low (Guillocheau et al., 2000).

The Paleogene sediments around the Armorican Massif are mainly carbonates. In the Paris Basin (Guillocheau et al., 2000), English Channel and Western Approaches (Evans, 1990), the maximum thickness of Paleogene rocks is $200 \mathrm{~m}$ (deposited over a period of $35 \mathrm{Ma}$ ). During the Cenozoic, the Armorican and Celtic Margins behaved as sediment-starved margins (Bourillet et al., 2003), with a maximum total sediment thickness below the shelf break of $2000 \mathrm{~m}$ on the Celtic Margin (Evans, 1990) and $1200 \mathrm{~m}$ on the Armorican Margin (Paquet et al., 2010).

Even though detailed, three-dimensional measurements of the siliciclastic sediment volumes are not available, available evidence supports a low denudation rate since Jurassic time, except along the borders of the two early Cretaceous rifts: Bay of Biscay and Western Approaches.

Burial depths are rather difficult to estimate in the absence of thermochronological data. Based on Jurassic and late Cretaceous sediment isopach maps available for the Paris Basin (Guillocheau et al., 2000; Lasseur, 2007) and on wells and seismic lines of the Western Approaches Basin (Evans, 1990; Ruffell, 1995), the amount of Mesozoic burial (estimated by an extrapolation of the thickness variations in the surrounding basins) is probably less than $1 \mathrm{~km}$ (certainly less than $400 \mathrm{~m}$ for the Jurassic) on the Paris Basin side; and is probably greater $(1-1.5 \mathrm{~km})$ on the Western Approaches Basin side.

\subsection{Nature of the Armorican planation surfaces}


Pre- and syn-Jurassic landforms (PS1 to PS4) are typical pediments, with upstream scarps organized in large flat-floored, valley-like structures reminiscent of the Namibian 'pedivalleys' mentioned by Dauteuil et al. (this volume).

The Armorican Surface (PS5) is a polygenetic planation surface. As mentioned above, its first stage of planation could have occurred at the time of deposition of the Wealden Group siliciclastic sediments (Berriasian-Barremian) and followed by lateritic weathering. The corresponding weathering materials are preserved within the Upper Barremian sediments of the Paris Basin ("Argiles et sables rouges panachés" - Meyer, 1976), confirming the occurrence of an early Cretaceous lateritic episode in northern France. During the late Cretaceous, this surface was covered by chalk. The earliest Cenozoic was a time of a widespread emersion of northern France, which involved a second period of intense weathering evidenced by the Clays-with-Flints (which can be in situ weathering profiles but also reworked deposits; see Quesnel, 2003 for discussions) with flints coming from the Late Cretaceous Chalk (Fig. 6). This surface was also bevelled by waves on its western Atlantic side, with evidence provided by occurrences of lag deposits consisting of rounded pebbles (see section 4.5). The exact age of the conglomerates, however, remains unknown. These facts imply that this polygenic surface was initially an etchplain, which was stripped twice by pediment-forming denudational processes and evolved more locally as a wave-cut surface. Landforms labelled as PS6 are pediments that could be responsible for the partial stripping of the early Cenozoic weathering profiles superimposed onto PS5 (stripped etchplain).

Direct constraints on the post-exhumation denudation depths of Mesozoic land surfaces PS1 to PS6 are difficult to acquire. The best available evidence is provided by preserved Cenozoic sedimentary sequences on the Armorican Massif (Durand, 1959; Guillocheau et al., 2003) and in its surrounding offshore basins (Evans, 1990; Guillocheau et al., 2000; Paquet et al., 2010). The Paleocene to middle Miocene stratigraphy is roughly half carbonate, half siliciclastic sediments. On the Armorican Massif, the Paleogene siliciclastic sediments are mostly claystones and siltstones, except for the silicified quartz-rich sandstones (so-called silcretes), which are of Ypresian to Bartonian age by analogy with those of the Paris Basin (Thiry et al., 1983; Thiry, 1999). The main change in the siliciclastic sedimentation record occurred during the late Miocene with the deposition of the "Red Sands" (Brault et al., 2004), which are coarse-grained estuarine sands filling a network of incised valleys distinct from the present-day one (Bonnet et al., 2000). 
These constraints suggest that, after stripping of the chalk, the amount of mechanical erosion until the late Miocene was low. The only evidence of alluvial deposits is the occurrence of silicified quartz-rich sands widely distributed throughout the Armorican Massif (from PS3 to PS6). As mentioned before, the climatic environment from the Paleocene to the middle Eocene was conducive to lateritic weathering. However, despite the widespread occurrence of its products (Fig. 3) the denudation attributable to chemical erosion is impossible to estimate. During the late Miocene, a major environmental change in base level and/or palaeoprecipitation promoted a shift away from the more diffuse regime of denudation towards more focused fluvial erosion. The pediment surfaces were abandoned in favour of the formation of a network of incised valleys involving two different successive systems: a late Miocene to Pliocene (Red Sands) network, which itself was overprinted by a middle to late Pleistocene valley network (Bonnet et al., 2000; Brault et al., 2004).

The low amount of mechanical erosion during Paleogene times, the widely distributed products of chemical erosion with no major base-level fall, and the focused erosion along incising rivers channels after the late Miocene probably explains the preservation of these Mesozoic exhumed landforms.

5.4. Patterns of landscape exhumation in response to crustal deformation

Both the early Cretaceous and Paleogene denudational intervals coincided with a relative base-level fall. This was due either to eustatic events or to tectonic deformations with uplift. Eustatic falls are insufficient to explain either of the land stripping events (1) because the resulting planation surface, i.e. the Armorican Surface (PS5), is currently deformed, and (2) because, according to the reference sea-level curve of Haq et al. (1987), the long-term sea level was higher during the early Cretaceous than during the Jurassic or slightly lower during the Paleogene than in the late Cretaceous — but still quite high in absolute terms (+200-250 m).

The two periods of early Cretaceous and earliest Cenozoic exhumation correspond instead to major periods of deformation of the surrounding basins. These have been reported by Ziegler (e.g. 1990) and affected much of West Europe. Early Cretaceous times record two deformation "events", the NeoCimmerian (intra-Berriasian: Jacquin and de Graciansky, 1998) and the Austrian ( Aptian-Albian boundary), which are respectively coeval with the early stages of the Biscay Rift and with the onset of 
oceanic accretion in that same geodynamic province (Montadert et al., 1979; Thinon et al., 2003). The latest Cretaceous to Oligocene is the period of convergence between Africa-lberia and Eurasia and of the resulting Pyrenean orogeny. In the eastern Pyrenees, Vergés et al. (1995) estimated that the maximum rate of crustal shortening occurred during Ypresian and Early Lutetian times. Along the Celtic and Armorican Margins, the ocean-continent boundaries underwent two spectacular tectonic inversions (Thinon et al., 2001): first during the latest Cretaceous, followed by a major but less precisely constrained event during the Eocene. In the Western Approaches Basin, a two-stage Eocene and Oligocene basin inversion has been documented (Le Roy et al., 2011). In the Paris Basin, two major periods of deformation occurred during the Maastrichtian and Selandian, with complete emersion of the basin and a sharp decrease in subsidence (Guillocheau et al., 2000). Likewise, the British Isles basins were deformed (inversion) and exhumed (Holford et al., 2005; Hillis et al., 2008) during the early Cretaceous (St-Georges Channel and East Irish Sea Basins) and early Cenozoic (Wessex-Weald Basin, East Irish Sea). The cause of this deformation remains debated, being either due to uplift as a result of the relative movements between Africa, Iberia and Eurasia (Hillis et al., 2008), or to the Paleocene-Eocene Icelandic plume (Davis et al., 2012). In conclusion, the two periods of exhumation (early Cretaceous and earliest Cenozoic) are chiefly linked to the relative movements between Africa, Iberia and Eurasia, first under a regime of plate divergence, and subsequently under a regime of convergence.

5.5. Is the geomorphological evolution of the Armorican Massif unique in western Europe?

Ages recently obtained for palaeoweathering mantles using isotopic geochemistry or palaeomagnetism (Gilg and Frei, 1997; Lippolt et al., 1998; Théveniaut et al., 2007; Ricordel-Prognon et al., 2010) have substantially modified our understanding of the long-term landscape evolution of continental Europe. These new data, summarized below, have provided Mesozoic and Cenozoic ages for most of the weathering materials (mainly laterites) and shed new light on the age of their associated landforms.

(1) Triassic: the albitization of bedrock outcrops is widely reported from the Variscan basement uplands of Europe (French Massif Central: Schmitt and Simon-Coincon, 1985; Ricordel et al., 2007, Parcerisa et al., 2010a; Bohemian Massif: Franke et al., 2009; Yao et al., 2010; Iberia: 
Franke et al., 2009; Parcerisa et al., 2010b). The dating of this event is based on their location beneath the Jurassic sedimentary cover (Schmitt and Simon-Coincon, 1985; Ricordel et al., 2007; Parcerisa et al., 2010a) and the early Triassic magnetic overprints (95\% reference pole confidence cone between $235 \mathrm{Ma}$ and $255 \mathrm{Ma}$, Ricordel et al., 2007).

(2) Late Jurassic to early Cretaceous: lateritic weathering profiles (including bauxites) and "Clayswith-Jurassic-Cherts" ("argiles à chailles": see Thiry et al., 2006 for a review) were dated (1) by their location below dated late Cretaceous sediments (Rioult et al., 1966; Estéoule-Choux et al., 1969; Vérague, 1974; 1977; Thiry et al., 2005; Théveniaut et al., 2007); (2) by radiometric methods (Lippolt et al., 1998; Yans et al., 2003); and (3) by palaeomagnetism (Théveniaut in Yans et al., 2003; Ricordel, 2007; Théveniaut et al., 2007; Quesnel et al., 2009a; Ricordel-Prognon et al., 2010). Palaeomagnetic data have been obtained from the French Massif Central (north: 120-130 Ma, Théveniaut in Quesnel et al., 2009a; south: $140 \pm$ $10 \mathrm{Ma}$ to $160 \mathrm{Ma}$ with the pole overlapped by the $95 \%$ confidence ellipse, Ricordel-Prognon et al., 2010); from the Ardennes (top of the profile: $120-110 \mathrm{Ma}$ and $131 \pm 10 \mathrm{Ma}$ to $126 \pm 10$ $\mathrm{Ma}$, intermediate part of the profile: 88-94 Ma, i.e. before the Campanian-Maastrichtian transgression, Yans et al., 2003); from the borders of the Ardennes with the Paris Basin (130 $\pm 10 \mathrm{Ma}$, Théveniaut et al., 2007); and from Saarland (142-120 Ma, Lippolt et al., 1998).

(3) Paleocene to Eocene: lateritic weathering profiles and "Clay-with-Flints" (developed on late Cretaceous chalk) have been dated in the French Massif Central (1) by their location below the dated Cenozoic sediments (see Klein, 1975 for a review), (2) by radiometric dating methods ( $45.5 \pm 1.2 \mathrm{Ma}$ to $40.8 \pm 1.8 \mathrm{Ma}$ : Gilg and Frei, 1997) and (3) by palaeomagnetism (50 $\pm 10 \mathrm{Ma}$, Théveniaut in Quesnel et al., 2009a; tentatively ca. 50 Ma, Ricordel, 2007). Widespread pedogenic silicifications (silcretes) have formed caprock on continental deposits that range in age from Paleocene to Eocene (Crié, 1878; Quesnel, 2003; Wyns et al., 2003; Quesnel et al., 2009b) or that are overlapped by Ypresian (northern France, Belgium, England; see Quesnel, 2003 for a review) to Bartonian (Châteauneuf, 1980; Quesnel, 2003; Quesnel et al., 2009b) strata.

Given their antiquity, these extant weathering profiles support the view that ancient landforms still exist on the uplands of western Europe. The fossil planation surfaces in the French Massif Central and in the Ardennes-Eifel massifs, where thermochronological and stratigraphic data are also 
available as constraints on the long-term denudation chronology, can serve here as relevant analogues to the Armorican Massif. In the Morvan (north-eastern French Massif Central), stratigraphic data (Lorenz, 1968; 1971) have indicated an occurrence of dated Sinemurian (base of the Jurassic) sediments on the top of the Morvan Plateau (Saint-Agnan area). In the same area, apatite fission-track data (Barbarand et al., 2013) suggest burial under late Cretaceous cover rocks followed by exhumation during the early Paleogene. Despite the relatively large uncertainty in the data (modelled thickness of late Cretaceous chalk cover: $400 \pm 300 \mathrm{~m}$ ), it follows that the topography preserved at the base of the Jurassic corresponding to the top of the Morvan Plateau was buried at least during the early Jurassic and the late Cretaceous, and exhumed at least during Paleocene to Eocene times.

In the Ardennes Massif, the High Ardennes Plateau (500 to $650 \mathrm{~m}$ ) displays (1) dated lateritic profiles (Dupuis et al., 1996) that indicate weathering periods ca. $130 \mathrm{Ma}$ (Hauterivian-Barremian, i.e. Lower Cretaceous; Yans and Dupuis, 2007), ca. 93 Ma (Cenomanian-Turonian, i.e. base of the Upper Cretaceous) and $21 \mathrm{Ma}$ (Lower Miocene); and (2) some late Cretaceous deposits (open marine chalk; Bless and Felder, 1989), while the lowest Condroz Plateau (200-350 m) is overlain by numerous early Cretaceous cover rocks (Wealden Group; Bless and Felder, 1989). Thermochronological data (Xu et al., 2009) suggest a final exhumation event occurring after $45 \mathrm{Ma}$ (middle Eocene) involving denudation depths of approximately 900 to $1300 \mathrm{~m}$. Again, the preservation on the Ardennes High Plateau of early Cretaceous weathering profiles and basal chalk deposits involving the later exhumation of approximately $1 \mathrm{~km}$ of rock indicate that this region is an exhumed topographic system at least early Cretaceous in age, which was buried by late Cretaceous chalk and exhumed at the time of the Cenozoic tectonic inversions of NW Europe.

Landscape evolution in both the northern part of the French Massif Central and the Ardennes is in most ways similar to the denudation chronology presented here for the Armorican Massif. Further landform studies are nonetheless required for these two massifs in order to refine our understanding of Jurassic burial in the Morvan, late Cretaceous chalk burial in the Massif Central and Ardennes, early Cretaceous laterite formation in the Ardennes and Massif Central, and early Paleogene exhumation of all these corresponding land surfaces.

\section{The main stages of Armorican landscape evolution}


Even though some points still need to be confirmed by further studies, the evolution of the Armorican relief can be summarized by the following chronology.

1. 250-190 Ma (Pre-Pliensbachian-Triassic ?): elaboration of pediments and pediplains PS1 to PS3 (Fig. 7). These land systems could be a legacy of the final stages of the eroding Triassic topography that supplied the Triassic sediments to the Paris and Wessex basins ("Buntsandstein" $=$ Induan-Anisian, and "Keuper" = Carnian-Norian siliciclastic sediments, Warrington and IvimeyCook, 1992; Bourquin and Guillocheau, 1996; McKie and Williams, 2009; Bourquin et al., 2011).

2. $183-170 \mathrm{Ma}$ (Pre-Bajocian to Toarcian-Aalenian): development of pediment population PS4. This might be related to a base-level fall caused by middle-Cimmerian crustal deformations, which have been well recorded in the Paris Basin (Jacquin and de Graciansky, 1998; Guillocheau et al., 2000).

3. $140-40$ (?) Ma (base of the Lower Cretaceous to pre-Bartonian?): first growth of the polygenetic Armorican Surface (PS5, Fig. 7). This surface records two events of the European-scale intraplate deformations (Neo-Cimmerian and Austrian events for the early Cretaceous, and Pyrenean deformations for the Paleogene), with a subsidence phase (late Cretaceous) in between. This surface experienced two periods of intense weathering under a hot and humid climate (Barremian and early Eocene). The first period of deformation generated the relief that supplied the Wealden Group siliciclastic sediments of the Paris Basin and possibly of the Western Approaches and Bay of Biscay rifts (Fig. 7).

4. 40(?)-6 Ma (Pre-Bartonian-Messinian): development of pediment population PS6 (Fig. 7). This period is still poorly understood, due to limited tectonic constraints on the formation of the socalled late Eocene to Oligocene rifts of Brittany.

5. 6-0 Ma (Messinian-Present): incision of two networks of V-shaped valleys. These incisions result from crustal uplift of the Armorican Massif - a trend shared with most of the north-western European basement uplands - in response to the convergence between Africa-Apulia and Eurasia, and consequently to the Alpine collision.

\section{Conclusions}


(1) The landscape of the Armorican Massif is an assemblage of six stepped planation surfaces (labelled PS1 to PS6) that were later incised by two successive networks of rivers. These mappable land surfaces have been deformed by epeirogenic movements, sometimes displaced by faults, so that each generation of land surface will not display uniform elevation bands across the regional landscape. A regional surface (PS5), previously recognized by de Martonne (1906), is here called the Armorican Planation Surface.

(2) These planation surfaces correspond to pediments and pediplains, i.e. nearly flat erosional surfaces with no concurrent depositional or erosional channelized rivers. The upslope boundary of any given pediment is typically a scarp or the steeper slope in the landscape. The regional Armorican Surface (PS5) is polygenetic and probably underwent two periods of etchplanation in humid, tropical climatic conditions.

(3) These planation surfaces are mostly pre-late Cretaceous, based on the age of existing pediment cover rocks. The three oldest (PS1 to PS3) are older than the Pliensbachian (191-183 Ma); PS4 is older than the Bajocian (170-168 Ma); being polygenetic, PS5 (the Armorican Surface) ranges from the base of the early Cretaceous to the base of the Bartonian (?) (140-40 Ma); and the youngest (PS6) is poorly constrained. The latter formed either before $40 \mathrm{Ma}$ (base of the Bartonian) or before 15 Ma (base of the middle Miocene).

(4) Most of these "old" landforms are exhumed land surfaces, i.e. they were buried by sediments and later exhumed by denudation. At least two cycles of burial and exhumation have been identified: (1) Jurassic burial followed by denudation during the early Cretaceous; and (2) late Cretaceous burial followed by denudation during latest Cretaceous to early Eocene times. The depths of burial are unknown, but were probably low given the small amount of siliciclastic sediment accumulations that were generated by subsequent denudation in the surrounding basins. Other Variscan basement uplands of western Europe such as the French Massif Central and the Ardennes Massif are also partly exhumed land systems which were buried by the Chalk sea during the late Cretaceous, i.e. at least once.

(5) The two periods of exhumation correspond to critical periods in the relative plate movements between Africa, Iberia and Eurasia. The first event is probably related to the birth and break-up of the rift between Iberia and Eurasia (Bay of Biscay), and the second to the convergence between these two plates (Pyrenean orogeny). 


\section{Acknowledgments}

We are grateful to the Région Bretagne for funding the Paul Bessin's Ph.D. thesis. We thank the BRGM (Bureau de Recherches Géologiques et Minières) for providing additional field funding, numerical geological maps and unpublished data for research well CDB1 (CINERGY project). We are thankful to the IGN (Institut Géographique National) for providing numerical DEM data. We also thank Dr. Sara Mullin and guest editor Yanni Gunnell for post-editing the English, and two anonymous reviewers for their constructive comments. 


\section{FIGURE CAPTIONS}

Figure 1: Main topographic units of the Armorican Massif and surrounding basins on a shaded-colour elevation map ( 3 arc-second resolution, NASA Shuttle Radar Topography Mission; projection: RGF Lambert 1993). Thick white line: limit between the Armorican Massif (Variscan basement) and the Paris Basin. Grey lines: main faults (NASZ: North Armorican Shear Zone; SASZ: South Armorican Shear Zone; MLT: Merlerault Fault; MA: Mayenne Fault; HUI: Huisne Fault).

Figure 2: 3D geometry (topography and geology), longitudinal and transverse cross-sections of three Armorican pediments of the Lower Normandy Plateau. A: Sélune Pediment; B: Falaise Pediment; C: Briouze Pediment. Geologic data from vectorized 1:50,000 geological maps of France (Sheets No. : 176-Gigot et al., 1999, 209-Langevin et al., 1984, 210-Ménillet et al., 1987, 211-Bambier et al., 1983, 212-Kuntz et al., 1989, 247-Dadet et al., 1984, 248-Vernhet et al., 1997, 249-Vernhet et al., 1995). Sketch B' represents the infill geometry of the Argentan Pediment by marine Middle Jurassic sediments coloured in blue (onlaps: thin white arrows).

Figure 3: Distribution of mappable weathering materials on the Armorican Massif, compiled from the 1:50,000 geological maps of France (BRGM; projection: RGF Lambert 1993). Maps with no data (empty boxes) correspond to pre-1990 geological maps, a time when surficial deposits were ignored by field geologists. Light grey hillshade: paleo-Proterozoic and Paleozoic cover rocks (dominated by shales) reported to illustrate the relationship between weathering and lithology. Weathering products on shale are mainly kaolinite. Thin grey line: limit between the Armorican Massif (Variscan basement) and the Paris Basin.

Figure 4: Detailed chronology and mapping of planation surfaces in the southern part of the Lower Normandy Plateau (see Fig. 5 for location; projection: RGF Lambert 1993). 4a: detailed map of the planation surfaces (PS1 to PS5); 4b: transverse and longitudinal cross-sections showing (1) the landform staircase, (2) the relative pediment chronology (from PS1: the oldest and most elevated surface, to PS5d: the youngest and least elevated surface); and (3) an age model derived from the preserved sedimentary rocks. 
Figure 5: Synthetic map of the Armorican Massif planation surfaces and their ages, compiled from a set of more detailed maps (projection: RGF Lambert 1993).

Figure 6: Map of late Cretaceous cover-rock vestiges on the Armorican Massif. Data from (1) Bauer et al., 2011; (2) Bigot, 1905; (3) Bonissent, 1870; (4) Borne et al., 1989; (5) Bourcart, 1950; (6) Brabant, 1965; (7) Chevalier and Borne, 1989; (8) Dangeard, 1928; (9) Deunff, 1953; (10) Durand, 1958; (11) Durand and Louail, 1971; (12) Durand et al., 1973; (13) Fleury et al., 1989; (14) Graindor, 1958; (15) Graindor and Marie, 1959; (16) Juignet, 1974; (17) Lautridou in Baize, 1998; (18) Lebesconte, 1882; (19) Noury, 1886; (20) Poncet, 1961; (21) Thinon et al., 2009; (22) Vernhet et al., 2009 (projection: RGF Lambert 1993).

Figure 7: Long-term landscape evolution of the Armorican Massif from Triassic to Oligocene time, emphasizing the main burial and exhumation phases. Here the evolution is summarized on a highly synthetic section showing only one plateau (Lower Normandy / Western Brittany) and the Paris border on the left-hand side and the Western Approaches on the right hand-side. The pre-Bajocian period of denudation (pediments PS4) has not been depicted. 


\section{References}

Baize, S., 1998. Tectonique, eustatisme et climat dans un système géomorphologique côtier; le nordouest de la France au Pléistocene; exemple du Cotentin (Normandie). Thèse de Doctorat de I'Université de Caen Basse-Normandie. and Documents du BRGM (1999) 289, 333 pp.

Ballèvre, M., Bosse, V., Ducassou, C., Pitra, P., 2009. Palaeozoic history of the Armorican Massif: Models for the tectonic evolution of the suture zones. Comptes Rendus Geoscience 341, 174-201.

Bambier, A., Beurrier, M., Doré, F., Enouf, C., Kuntz, G., Langevin, C., Lautridou, J.P., Rioult, M., Verron, G., Villey, M., 1983. Notice explicative, Carte géologique de France (scale 1:50,000), feuille Flers-de-l'Orne (211). BRGM, Orléans, France, 44 pp. Geological map by Beurrier, M.Villey, M., Lautridou, J. P., Rioult, M., Kuntz, G., Doré, F., Enouf, C., Langevin, C., Verron, G., Bambier, A., 1982.

Barbarand, J., Quesnel, F., Pagel, M., 2013. Lower Paleogene denudation of Upper Cretaceous cover of the Morvan Massif and southeastern Paris Basin (France) revealed by AFT thermochronology and constrained by stratigraphy and paleosurfaces. Tectonophysics 608 , 1310-1327.

Bauer, H., Saint-Marc, P., Châteauneuf, J.-J., Bourdillon, C., Guillocheau, F., 2011. Paléoenvironnements et paléoclimats enregistrés dans le bassin éo-oligocène de Rennes. Apports du forage CDB1 (projet CINERGY). 13ème congrès français de sédimentologie (Dijon, France). Publication de l'Association française de Sédimentologie, http://hal-brgm.archivesouvertes.fr/hal-00630664.

Bigot, A., 1905. Histoire naturelle de la Presqu'île du Cotentin - I. Géologie, Cherbourg et le Cotentin. Congrès de l'Association française pour l'avancement des sciences (Cherbourg), 3-10 août 1905. Imprimerie Emile le Maout. Cherbourg, France, pp. 1-26.

Bless, M.J.M., Felder, P.J., 1989. Note on the Late Cretaceous of Hockai (Hautes Fagnes, NE Belgium). Annales de la Société Géologique de Belgique 112, 47-56.

Bonissent, M., 1870. Essai géologique sur le département de la Manche, Extrait des Mémoires de la Société des Sciences naturelles de Cherbourg et d'Avranches. Imprimeur Charles Feuardent, Cherbourg, France, $427 \mathrm{pp}$.

Bonnet, S., 1997. Tectonique et dynamique du relief : Le socle armoricain au Pléistocène. Thèse de Doctorat de l'Université de Rennes 1, and Mémoires de Géosciences Rennes (1998) 86, 352 pp.

Bonnet, S., Guillocheau, F., Brun, J.-P., Van Den Driessche, J., 2000. Large-scale relief development related to Quaternary tectonic uplift of a Proterozoic-Paleozoic basement; the Armorican Massif, NW France. Journal of Geophysical Research - Solid Earth 105, 19,273-19,288.

Borne, V., Chevalier, M., Olivier-Pierre, M.F., 1989. Les premiers dépôts paléogènes (yprésiens) de la bordure méridionale du Massif armoricain; aspects sédimentologique, tectonique et paléogeographique. Géologie de la France 1-2, 11-20.

Bourcart, J., 1950. Le Littoral breton du Mont Saint-Michel au Finistère. Bulletin d'information du Comité d'Océanographie et d'Etude des Côtes 2, 21-39, 56-72, and 97-115.

Bourcart, J., Guilcher, A., Tricart, J., 1950. Découverte d'une grotte marine avec galets vers 135 mètres au Menes Lus en Telgruc (Finistère). Compte Rendu sommaire de la Société Géologique de France 9-10, 158-160.

Bourillet, J.-F., Reynaud, J.Y., Baltzer, A., Zaragosi, S., 2003. The "Fleuve Manche": the submarine sedimentary features from the outer shelf to the deep-sea fans. Journal of Quaternary Science 18, 261-282.

Bourquin, S., Guillocheau, F., 1996. Keuper stratigraphic cycles in the Paris basin and comparison with cycles in other peritethyan basins (German basin and Bresse-Jura basin). Sedimentary Geology 105, 159-182. 
Bourquin, S., Bercovici, A., López-Gómez, J., Diez, J.B., Broutin, J., Ronchi, A., Durand, M., Arché, A., Linol, B., Amour, F., 2011. The Permian-Triassic transition and the onset of Mesozoic sedimentation at the northwestern peri-Tethyan domain scale: Palaeogeographic maps and geodynamic implications. Palaeogeography, Palaeoclimatology, Palaeoecology 299, 265-280.

Brabant, P., 1965. Contribution à l'étude sédimentologique des formations sableuses aux environs de Ballots et La Guerche. MSc Dissertation, Université de Rennes, Rennes, 40 pp.

Brault, N., 2002. Ressources du sous-sol et environnement en Bretagne; genèse, géométrie et propriétés de différents types d'aquifères. PhD thesis, Université de Rennes 1 and Mémoires de Géosciences Rennes (2008) 127, 240 pp.

Brault, N., Bourquin, S., Guillocheau, F., Dabard, M.P., Bonnet, S., Courville, P., Estéoule-Choux, J., Stepanoff, F., 2004. Mio-Pliocene to Pleistocene paleotopographic evolution of Brittany (France) from a sequence stratigraphic analysis; relative influence of tectonics and climate. Sedimentary Geology 163, 175-210.

Bremer, H., 1993. Etchplanation; review and comments of Büdel's model. Zeitschrift für Geomorphologie Supplementband 92, 189-200.

Brown, E.H., 1968. Planation surface. In: Fairbridge, R.W. (Ed.), Encyclopedia of Geomorphology. Encyclopedia of Earth Sciences series. Reinhold Book Corporation, New York, pp. 856.

Brunsden, D., 1963. The denudation chronology of the river Dart. Transactions and Papers (Institute of British Geographers) 32, 49-63.

Büdel, J., 1957. Die 'doppelten Einebnungsflaechen' in den feuchten Tropen. Zeitschrift für Geomorphologie 1, 201-228.

Chantraine, J., Egal, E., Thiéblemont, D., Le Goff, E., Guerrot, C., Ballèvre, M., Guennoc, P., 2001. The Cadomian active margin (North Armorican Massif, France): a segment of the North Atlantic Panafrican belt. Tectonophysics 331, 1-18.

Châteauneuf, J.-J., 1980. Palynostratigraphie et paléoclimatologie de l'Eocène supérieur et de I'oligocène du Bassin de Paris (France). Thèse de Doctorat d'Etat, Université Pierre et Marie Curie (Paris VI). Mémoires du BRGM 116, 357 pp.

Chevalier, M., Borne, V., 1989. Remise en question de l'attribution 'Sables rouges pliocènes' aux formations détritiques du domaine du Lac de Grand-Lieu (Loire-Atlantique). Géologie de la France 1-2, 277-284.

Cooke, R.U., 1970. Morphometric analysis of pediments and associated landforms in the western Mohave Desert, California. American Journal of Science 269, 26-38.

Courville, P., Bongrain, M., 2003. Les Pectinidae miocènes des faluns (Ouest de la France); Intérêts biostratigraphiques des associations. Annales de Paléontologie 89, 125-151.

Crié, L., 1878. Recherches sur la végétation de l'Ouest de la France à l'époque tertiaire. Thèse de Doctorat de la Faculté des Sciences de Paris. Masson, Paris, 72 pp.

Dadet, P., Beurrier, M., Lautridou, J.P., 1984. Notice explicative, Carte géologique de France (scale 1:50,000), feuille Saint-Hilaire-du-Harcouët (247). BRGM, Orléans, France, 26 pp. Geological map by Lautridou, J. P., Dadet, P., Beurrier, M., Le Metour, J.

Dangeard, L., 1928. Observations de géologie sous-marine et d'océanographie relatives à la Manche. Annales de l'Institut Océanographique (nouvelle série) 6, 295 pp.

Dauteuil, O., Bessin, P., Guillocheau, F., 2014. Topographic growth around the Orange River valley, southern Africa: a Cenozoic record of crustal deformation and climatic change. This volume.

Davis, M.W., White, N.J., Priestley, K.F., Baptie, B.J., Tilmann, F.J., 2012. Crustal structure of the British Isles and its epeirogenic consequences. Geophysical Journal International 190, 705725.

de Martonne, E., 1906. La pénéplaine et les côtes bretonnes. Annales de Géographie 15, 213-236 and 299-328.

De Reu, J., Bourgeois, J., Bats, M., Zwertvaegher, A., Gelorini, V., De Smedt, P., Chu, W., Antrop, M., De Maeyer, P., Finke, P., Van Meirvenne, M., Verniers, J., Crombé, P., 2013. Application of the topographic position index to heterogeneous landscapes. Geomorphology 186, 39-49. 
Deunff, J., 1953. Présence de craie à Locquirec (Finistère). Compte Rendu sommaire de la Société géologique de France 5-6, 68-69.

Dikau, R., Brabb, E.E., Mark, R.M., 1991. Landform classification of New Mexico by computer. 01961497, U. S. Geological Survey, Reston, VA, 19pp.

Dohrenwend, J.C., Parsons, A.J., 2009. Pediments in arid environments. In: Parsons, A.J., Abrahams, A.D. (Eds.), Geomorphology of Desert Environments, 2nd edn. Springer, International, pp. 377-411.

Doré, F., Dupret, L., Le Gall, J., Chalot-Prat, F., 1977. Notice explicative, Carte géologique de France (scale 1:50,000), feuille La Ferté-Macé (250). BRGM, Orléans, France, 31 pp. Geological map by Doré, F., Dupret, L., Le Gall, J., Chalot-Prat, F.

Dugué, O., 2007. Le Massif armoricain dans l'évolution mésozoïque et cénozoïque du nord-ouest de I'Europe - Contrôles tectonique, eustatique et climatique d'un bassin intracratonique (Normandie, mer de la Manche, France). Mémoire d'Habilitation à Diriger les Recherches (HDR) de l'Université de Caen Basse-Normandie, and Mémoires de Géosciences Rennes (2007), Hors-série 6, 346 pp.

Dugué, O., Lautridou, J.P., Quesnel, F., Poupinet, N., Clet, M., Camuzard, J.P., Coutard, S., Bourdillon, C., Freslon, M., Auffret, J.P., Laville, E., Gain, O., 2005. Le Cotentin du Mésozoïque au Cénozoïque. Bulletin d'Information des Géologues du Bassin de Paris 42, 6-68.

Dugué, O., Auffret, J.-P., Poupinet, N., 2007. Cenozoic shelly sands in the Cotentin (Armorican Massif, Normandy, France): A record of Atlantic transgressions and intraplate Cenozoic deformations. Comptes Rendus Geoscience 339, 110-120.

Dupuis, C., Charlet, J.-M., Dejonghe, L., Thorez, J., 1996. Reconnaissance par carottage des paléoaltérations kaolinisées mésozoiques de la Haute Ardenne (Belgique); Le sondage de Transinne (194E-495); Premiers résultats. Annales de la Société Géologique de Belgique 119, 91-109.

Durand, S., 1958. L'analyse pollinique montre que le remaniement du Crétacé, au pied du Sillon-deBretagne, date de l'Eocène inférieur. Comptes Rendus de l'Académie des Sciences 247, 17531756.

Durand, S., 1959. Le Tertiaire de Bretagne; étude stratigraphique, sédimentologique et tectonique. Thèse de Doctorat d'Etat, Université de Rennes 1 and Mémoires de la Société Géologique et Minéralogique de Bretagne (1960) 12, 389 pp.

Durand, S., Louail, J., 1971. Découverte d'un dépôt cénomanien fossilifère à Neau (Mayenne). Comptes Rendus de l'Académie des Sciences, Série D 273, 1179-1181.

Durand, S., Milon, Y., 1959. Relations des sédimentations crétacées et tertiaires en Bretagne. Comptes Rendus du 84ème Congrés National des Sociétés Savantes (Dijon). Section des Sciences, 146-162.

Durand, S., Ollivier-Pierre, M.-F., 1969. Observations nouvelles sur la présence du pollen de palmier Nypa dans l'Eocène de l'ouest de la France et du sud de l'Angleterre. Bulletin de la Société Géologique et Minéralogique de Bretagne, Série C 1, 49-57.

Durand, S., Estéoule-Choux, J., Ollivier-Pierre, M.-F., Rey, R., 1973. Découverte d'Oligocène reposant sur du Cénomanien dans un quartier sud de la ville de Laval (Mayenne). Comptes Rendus de l'Académie des Sciences, Série D 276, 701-703.

Dury, G.H., 1972. A partial definition of the term pediment with field tests in humid-climate areas of southern England. Institute of British Geographers Transactions 57, 139-151.

Elvhage, C., Lidmar-Bergström, K., 1987. Some working hypotheses on the géomorphology of Sweden in the light of a new relief-map. Geografiska Annaler 69A, 343-358.

Enay, R., Mangold, C., Cariou, E., Contini, D., Debrand-Passard, S., Donze, P., Gabilly, J., LefavraisRaymond, A., Mouterde, R., Thierry, J., 1980. Synthèse paléogéographique du Jurassique Français. Documents du Laboratoire de géologie, Lyon, Hors-Série 5, 210 pp.

Esmerode, E.V., Surlyk, F., 2009. Origin of channel systems in the Upper Cretaceous Chalk Group of the Paris Basin. Marine and Petroleum Geology 26, 1338-1349. 
Estéoule-Choux, J., 1970. Contribution à l'étude des argiles du Massif armoricain; argiles des altérations et argiles des bassins sédimentaires tertiaires. Thèse de Doctorat d'Etat, Université de Rennes 1, and Mémoires de la Société Géologique et Minéralogique de Bretagne 14, $319 \mathrm{pp}$.

Estéoule-Choux, J., 1983. Altérations et silicifications au Tertiaire dans le Massif armoricain. Géologie de la France 2, 345-352.

Estéoule-Choux, J., Estéoule, J., Louail, J., 1969. Sur la présence d'un dépôt à kaolinite et à gibbsite entre le Bajocien et le Cénomanien en Maine-et-Loire. Comptes Rendus de l'Académie des Sciences, Série D 268, 891-893.

Estéoule-Choux, J., Ollivier-Pierre, M.-F., 1973. Présence de dépôts lacustres d'âge Eocène en Bretagne Centrale, a la Trinité-Porhoët (Morbihan). Comptes Rendus de l'Académie des Sciences, Série D 277, 633-635.

Evans, C.D.R., 1990. The geology of the Western English Channel and its Western Approaches. DSDP, ODP report. HMSO for the British Geological Survey, London, $93 \mathrm{pp}$.

Ferronnière, G., 1921. Une carrière de grès tertaires à plantes à Berreau-en-Missilac (LoireInférieure). Bulletin de la Société Géologique et Minéralogique de Bretagne 2, 395-397.

Fily, G., 1989. Dynamique tidale sur la plate-forme carbonatée nord-armoricaine au Bathonien moyen. Bulletin de la Société Géologique de France 5, 1137-1144.

Fleury, L., Clement, J.P., Menillet, F., Moguedet, G., Vinchon, C., Farjanel, G., 1989. Les sables rouges et graviers des plateaux et des karsts du Maine méridional; Etude sédimentologique. Géologie de la France 1-2, 257-277.

Franke, C., Thiry, M., Jelenska, M., Kodzialko-Hofmokl, M., Lagroix, F., Parcerisa, D., Szuszkiewicz, A., Turniak, K., 2009. Remagnetization of Variscan massifs and reconstruction of the Triassic paleosurface in Europe. AGU 2009 fall meeting. EOS Transactions 90 (52, suppl.), abstractGP43A-0834.

Gautier, M., 1947. La Bretagne centrale. Etude géomorphologique. PhD thesis, Université de Rennes and $\mathrm{H}$. Potier Editions, La Roche-sur-Yon, $453 \mathrm{pp}$.

Gigot, P., Dupret, L., Le Gall, J., with inputs from Coutard, J.-P., Ozouf, J.-C., Pay, T., Lecointe, A., Desloges, J., Deroin, J.-P., 1999. Notice explicative, Carte géologique de France (scale 1:50,000), feuille Falaise (176). BRGM, Orléans, France, 154 pp. Geological map by Gigot, P., Dupret, L., Le Gall, J.

Gilg, H.A., Frei, R., 1997. Isotope dating of residual kaolin deposits in Europe (Tirschenreuth, Germany and St. Yrieix, France). Proceedings of the 30th International Geological Congress (Beijing, China) 9, 123-132.

Graindor, M.-J., 1958. Affleurement de calcaire crétacé au sud des îles Chausey. Bulletin de la Société linéenne de Normandie (9ème série) 9, 109-109.

Graindor, M.-J., Marie, P., 1959. Le Sénonien inférieur au SSW des îles Chausey (Manche). Compte Rendu sommaire de la Société Géologique de France 3, 56-58.

Guilcher, A., 1948. Le relief de la Bretagne méridionale, de la baie de Douarnenez à la Vilaine. Thèse de Doctorat de l'Université de Paris., H. Potier, La Roche-sur-Yon, 682 pp.

Guilcher, A., 1949. Le Relief des monts d'Arrée. Annales de Bretagne 56, 233-248.

Guilcher, A., 1974. Pénéplaine ou pédiplaine de l'Ouest de la France, d'après Claude Klein. Annales de Géographie 83, 381-393.

Guilcher, A., Saint-Réquier, A., 1969. Les galets et les sables du Menez Lus (Finistère) et leur signification morphologique. Norois 62, 245-251.

Guillocheau, F., Robin, C., Allemand, P., Bourquin, S., Brault, N., Dromart, G., Friedenberg, R., Garcia, J.-P., Gaulier, J.-M., Gaumet, F., Grosdoy, B., Hanot, F., Le Strat, P., Mettraux, M., Nalpas, T., Prijac, C., Rigollet, C., Serrano, O., Grandjean, G., 2000. Meso-Cenozoic geodynamic evolution of the Paris Basin; 3D stratigraphic constraints. Geodinamica Acta 13, 189-245.

Guillocheau, F., Brault, N., Thomas, E., Barbarand, J., Bonnet, S., Bourquin, S., Estéoule-Choux, J., Guennoc, P., Menier, D., Néraudeau, D., Proust, J.-N., Wyns, R., 2003. Histoire géologique du 
Massif armoricain depuis 140 Ma (Crétace-Actuel). Bulletin d'Information des Géologues du Bassin de Paris 40, 13-28.

Hallégouët, B., 1972. Découverte d'un gisement de galets marins vers $200 \mathrm{~m}$ d'altitude, près de Scaër (Finistère). Comptes Rendus de l'Académie des Sciences, Série D 275, 1859-1861.

Hallégouët, B., 1976. Les anciens dépôts marins et fluviatiles de la vallée de l'Elorn (Finistère). Norois 89, 55-72.

Hammond, E.H., 1964. Analysis of properties in land form geography; an application to broad-scale land form mapping. Annals of the Association of American Geographers 54, 11-19.

Hancock, J.M., Rawson, P.F., 1992. Cretaceous. Geological Society of London, Memoirs 13, 131-139. Haq, B.U., Hardenbol, J., Vail, P.R., 1987. Chronology of fluctuating sea levels since the Triassic. Science 235, 1156-1167.

Hillis, R.R., Holford, S.P., Green, P.F., Doré, A.G., Gatliff, R.W., Stoker, M.S., Thomson, K., Turner, J.P., Underhill, J.R., Williams, G.A., 2008. Cenozoic exhumation of the southern British Isles. Geology 36, 371-374.

Holford, S.P., Green, P.I.F., Turner, J.P., 2005. Palaeothermal and compaction studies in the Mochras borehole (NW Wales) reveal early Cretaceous and Neogene exhumation and argue against regional Palaeogene uplift in the southern Irish Sea. Journal of the Geological Society of London 162, 829-840.

Huggett, R.J., 2011. Fundamentals of Geomorphology, 3rd edition. Routledge fundamentals of physical geography series. Routledge, New York, 516 pp.

IGN, 2011. BD ALTI - 25 m resolution. Institut Géographique National (IGN), France.

Jacquin, T., de Graciansky, P.-C., 1998. Major transgressive/regressive cycles; the stratigraphic signature of European basin development. In: de Graciansky, P.-C., Hardenbol, J., Jacquin, T., Vail, P.R. (Eds.), Mesozoic and Cenozoic sequence stratigraphy of European basins. SEPM (Society for Sedimentary Geology), Special Publication. Society for Sedimentary Geology (SEPM) 60, pp. 15-29.

Jarvis, A., Reuter, H., Nelson, A., Guevara, E., 2008. Hole-filled SRTM for the globe, Version 4. CGIARCSI SRTM 90m Database. International Center for Tropical Agriculture, Cali, Columbia. http://srtm.csi.cgiar.org

Jessen, O., 1938. Tertiaerklima und Mittelgebirgsmorphologie. Zeitschrift der Gesellschaft für Erdkunde zu Berlin 1-2, 36-49.

Johansson, M., Olvmo, M., Lidmar-Bergström, K., 2001. Inherited landforms and glacial impact of different palaeosurfaces in Southwest Sweden. Geografiska Annaler 83A, 67-89.

Jones, D.K.C., 1999. Evolving models of the Tertiary evolutionary geomorphology of southern England, with special reference to the Chalklands. Geological Society of London, Special Publications 162, 1-23.

Juignet, P., 1974. La transgression crétacée sur la bordure orientale du Massif armoricain. Aptien, Albien, Cénomanien de Normandie et du Maine. Le stratotype du Cénomanien. Thèse de Doctorat d'Etat de I'Université de Caen Basse-Normandie. Université de Caen, France, 810 pp.

Juignet, P., Lebert, A., Legall, J., 1984. Notice explicative, Carte géologique de France (scale 1;50,000), feuille Fresnay-sur-Sarthe (287). BRGM, Orléans, France, 56 pp. Geological map by Juignet, P., Lebert, A., Legall, J., Pottier, Y., Doré, F., 1983.

Kerforne, F., 1921. Notice Géologique sur le département d'Ille-et-Vilaine. Bulletin de la Société Géologique et Minéralogique de Bretagne 2, 16-70.

King, L.C., 1953. Canons of landscape evolution. Geological Society of America Bulletin 64, 721-751.

Klein, C., 1975. Massif Armoricain et Bassin Parisien. Contribution à l'étude géologique et géomorphologique d'un massif ancien et de ses enveloppes sédimendaires (Normandie, Maine, Anjou, Tourain, Poitou septentrional et contrées adjacentes). Thèse de Doctorat d'Etat, Université de Bretagne Occidentale (Brest). Fondation Baulig (Tome XII), Strasbourg, 882 pp. 
Klein, C., 1990. L'évolution géomorphologique de l'Europe Hercynienne occidentale et centrale Apsects régionaux et essai de synthèse, Mémoires et documents de Géographie. Editions du CNRS, 177 pp.

Kuntz, G., Ménillet, F., Le Gall, J., Rioult, M., with inputs from Callier, L., Pellerin, J., de la Quérière, P., Vautrelle, C., Verron, G., 1989. Notice explicative, Carte géologique de France (scale 1:50,000), feuille Argentan (212). BRGM, Orléans, France, 99 pp. Geological map by Kuntz, G., Ménillet, F., Le Gall, J., Rioult, M., Pellerin, J., de la Quérière, P., Vautrelle, C., Gérard, J., Doré, F., Callier, L., Verron, G.

Lachassagne, P., Wyns, R., Dewandel, B., 2011. The fracture permeability of hard rock aquifers is due neither to tectonics, nor to unloading, but to weathering processes. Terra Nova 23, 145-161.

Lageat, Y., 2014. The "Pink Granite" Coast (Northern Brittany). In: Fort, M., André, M.-F. (Eds.), Landscapes and Landforms of France. World Geomorphological Landscapes. Springer, Dordrecht, pp. 53-60.

Langevin, C., Minoux, L., L'homer, A., Lautridou, J.P., Dassibat, C., Verron, G., 1984. Notice explicative, Carte géologique de France (scale 1:50,000), feuille Avranches (209). BRGM, Orléans, France, 54 pp. Geological map by Langevin, C., Minoux, L., L'homer, A., Lautridou, J. P., Dassibat, C., Verron, G., Beurrier, M., Villey, M.

Lasseur, E., 2007. La craie du Bassin de Paris (Cénomanien-Campanien, Crétace supérieur); sédimentologie de facies, stratigraphie séquentielle et géometrie 3D. PhD thesis, Université de Rennes 1, and Mémoires de Géosciences Rennes 129, 435 pp.

Le Roy, P., Gracia-Garay, C., Guennoc, P., Bourillet, J.-F., Reynaud, J.-Y., Thinon, I., Kervevan, P., Paquet, F., Menier, D., Bulois, C., 2011. Cenozoic tectonics of the Western Approaches Channel basins and its control of local drainage systems. Bulletin de la Société Géologique de France 182, 451-463.

Lebesconte, M.-P., 1882. De l'apport par la mer, sur les plages bretonnes, de roches et fossiles du Calcaire grossier et du Crétacé. Bulletin de la Société Géologique de France 10, 68-73.

Lécuyer, C., Grandjean, P., Paris, F., Robardet, M., Robineau, D., 1996. Deciphering "temperature" and "salinity" from biogenic phosphates: the $\delta^{18} \mathrm{O}$ of coexisting fishes and mammals of the Middle Miocene sea of western France. Palaeogeography, Palaeoclimatology, Palaeoecology $126,61-74$.

Lidmar-Bergström, K., 1989. Exhumed Cretaceous landforms in South Sweden. Zeitschrift für Geomorphologie N.F. Supplementband 72, 21-40.

Lidmar-Bergström, K., 1995. Relief and saprolites through time on the Baltic Shield. Geomorphology $12,45-61$.

Lidmar-Bergström, K., 1996. Long term morphotectonic evolution in Sweden. Geomorphology 16, 33-59.

Lidmar-Bergström, K., 1999. Uplift histories revealed by landforms of the Scandinavian domes. Geological Society of London, Special Publications 162, 85-91.

Lidmar-Bergström, K., Olsson, S., Olvmo, M., 1997. Palaeosurfaces and associated saprolites in southern Sweden. Geological Society of London, Special Publications 120, 95-124.

Lidmar-Bergström, K., Bonow, J.M., Japsen, P., 2013. Stratigraphic Landscape Analysis and geomorphological paradigms: Scandinavia as an example of Phanerozoic uplift and subsidence. Global and Planetary Change 100, 153-171.

Lippolt, H.J., Brander, T., Mankopf, N.R., 1998. An attempt to determine formation ages of goethites and limonites by (U-Th)/He dating. Neues Jahrbuch für Mineralogie, Monatshefte, 505-528.

Lorenz, J., 1968. La transgression secondaire sur le socle du Morvan; exemple pris dans la région de Pouilly-en-Auxois (Côte-d'Or). Compte Rendu sommaire de la Société géologique de France 5 142-142.

Lorenz, J., 1971. Sur l'age sinémurien des lambeaux de terrains sédimentaires silicifiés sur la partie centre-nord du Morvan (région de Saint-Agnan). Bulletin du Bureau de Recherches Géologiques et Minières, Section 1: Géologie de la France 1, 35-45. 
McKie, T., Williams, B., 2009. Triassic palaeogeography and fluvial dispersal across the northwest European Basins. Geological Journal 44, 711-741.

Ménillet, F., Trautmann, F., with inputs from Fourniguet, J., Janjou, D., Langevin, C., Lautridou, J.P., de la Quérière, P., Vautrelle, C., Verron, G., 1987. Notice explicative, Carte géologique de France (scale 1:50,000), feuille Mortain (210). BRGM, Orléans, France, 70 pp. Geological map by Ménillet, F., Trautmann, F., Fourniguet, J., Janjou, D., Langevin, C., Lautridou, J. P., de la Quérière, P., Vautrelle, C., Verron, G, Villey, M., Laouenan, J. P., Walker, P.

Ménillet, F., Rioult, M., with inputs from Havlicek, P., Lecointe, A., Monciardini, C., Pascaud, P., 1994. Notice explicative, Carte géologique de France (scale 1:50,000), feuille Vimoutiers (177). BRGM, Orléans, France, 91 pp. Geological map by Ménillet, F., Gonzalès, G., Kuntz, G., Rioult, M., Havlicek, P., Lebret, P.

Ménillet, F., Gérard, J., with inputs from Hérard, B., Langevin, C., Lemoine, B., Leturcq, T., Pellerin, J., Quesnel, F., 1997. Sées Notice explicative, Carte géologique de France (scale 1:50,000), feuille Sées (213). BRGM, Orléans, France, 103 pp. Geological map by Menillet, F., Langevin, C., Lemoine, B., Leturcq, T., Pellerin, J., Quesnel, F., Gérard, J.

Meyer, R., 1976. Continental sedimentation, soil genesis and marine transgression in the basal beds of the Cretaceous in the east of the Paris Basin. Sedimentology 23, 235-253.

Meynier, A., 1940. La Formation du réseau hydrographique de la Vilaine, étude géographique. Annales de Bretagne 47, 153-184.

Meynier, A., 1951. Toutes les pénéplaines armoricaines sont-elles des pédiments ? Bulletin de la Section de Géographie. Actes du 76ème Congrès des Sociétés Savantes (Rennes) 64, 135147.

Meynier, A., 1952. A propos des "pédiments" armoricains. Annales de Bretagne 59, 127-128.

Migoń, P., 1997. Tertiary etchsurfaces in the Sudetes Mountains, SW Poland: a contribution to the pre-Quaternary morphology of Central Europe. Geological Society of London, Special Publications 120, 187-202.

Migoń, P., 1999. Inherited landscapes of the Sudetic Foreland (SW Poland) and implications for reconstructing uplift and erosional histories of upland terrains in Central Europe. Geological Society of London, Special Publications 162, 93-107.

Migoń, P., 2004a. Planation surface. In: Goudie, A.S. (Ed.), Encyclopedia of Geomorphology. Routledge, London and New-York, pp. 788-792.

Migoń, P., 2004b. Etching, etchplain and etchplanation. In: Goudie, A.S. (Ed.), Encyclopedia of Geomorphology. Routledge, London and New-York, pp. 345-347.

Migoń, P., Lidmar-Bergström, K., 2001. Weathering mantles and their significance for geomorphological evolution of central and northern Europe since the Mesozoic. EarthScience Reviews 56, 285-324.

Miller, P.C., Bradbury, D.E., Hajek, E., LaMarche, V., Thrower, N.J.W., 1977. Past and present environment. In: Mooney, H.A. (Ed.), Convergent evolution in Chile and California: Mediterranean Climate Ecosystems. Dowden, Hutchinson \& Ross, Stroudsburg PA, pp. 27-72.

Millot, G., 1980. Les grands aplanissements des socles continentaux dans les pays subtropicaux, tropicaux et désertiques, Livre jubilaire du cent cinquantenaire 1830-1980. Mémoire Hors série, 10. Société Géologique de France, Paris , pp. 295-305.

Milon, Y., 1932. L'extension des formations sidérolithiques éocènes dans le centre de la Bretagne. Comptes Rendus de l'Académie des Sciences 194, 1360-1361.

Montadert, L., Roberts, D.G., de Charpal, O., Guennoc, P., 1979. Rifting and subsidence of the northern continental margin of the Bay of Biscay. Initial Reports of the Deep Sea Drilling Project 48, 1025-1060.

Morgan, J.M., Lesh, A.M., 2005. Developing landform maps using ESRI's ModelBuilder, ESRI User Conference 2005, Proceedings, Redlands, CA, 11p.

Mosbrugger, V., Utescher, T., Dilcher, D.L., 2005. Cenozoic continental climatic evolution of Central Europe. Proceedings of the National Academy of Sciences 102, 14,964-14,969.

Musset, R., 1917. Le Bas-Maine - étude géographique. Librairie Armand Colin, Paris, 496 pp. 
Musset, R., 1922. The geographical characteristics of western France. Geographical Review 12, 8499.

Musset, R., 1928. Le relief de la Bretagne occidentale. Annales de Géographie 37, 209-223.

Noury, C., 1886. Géologie de Jersey. F. Savy Editions, Paris, 177 pp.

Ollivier-Pierre, M.-F., 1980. Etude palynologique (spores et pollens) de gisements paléogènes du Massif armoricain; stratigraphie et paléogéographie. Thèse de Doctorat d'Etat, Université de Rennes 1 and Memoires de la Société Géologique et Minéralogique de Bretagne 25, 239 p.

Ollivier-Pierre, M.-F., Gruas-Cavagnetto, C., Roche, E., Schuler, M., 1987. Eléments de flore de type tropical et variations climatiques au Paléogène dans quelques bassins d'Europe nordoccidentale. Mémoires et Travaux de l'Institut de Montpellier 17, 173-205.

Ollivier-Pierre, M.-F., Riveline, J., Lautridou, J.P., Cavelier, C., 1988. Le fossé de Céaucé (Orne) et les bassins ludiens (Eocène supérieur) de la partie orientale du Massif armoricain; sédimentologie, paléontologie intérêt stratigraphique, paléogéographique et tectonique. Géologie de la France 1, 51-60.

Ollivier-Pierre, M.-F., Maupin, C., Estéoule-Choux, J., Sittler, C., 1993. Transgression et paléoenvironnement à l'Oligocène en Bretagne (France); sédimentologie, micropaléontologie, palynologie et palynofaciès du Rupélien du Bassin de Rennes. Palaeogeography, Palaeoclimatology, Palaeoecology 103, 223-250.

Paquet, F., Menier, D., Estournès, G., Bourillet, J.-F., Leroy, P., Guillocheau, F., 2010. Buried fluvial incisions as a record of Middle-Late Miocene eustasy fall on the Armorican Shelf (Bay of Biscay, France). Marine Geology 268, 137-151.

Parcerisa, D., Thiry, M., Schmitt, J.M., 2010a. Albitisation related to the Triassic unconformity in igneous rocks of the Morvan Massif (France). International Journal of Earth Sciences 99, 527544.

Parcerisa, D., Casas, L., Franke, C., Gomez-Gras, D., Lacasa, G., Nunez, J.A., Thiry, M., 2010b. Geomorphological stability of Permo-Triassic albitized profiles; case study of the MontsenyGuilleries High (NE Iberia). Geophysical Research Abstracts 12, EGU2010-15607.

Pécsi, M., 1970. Surfaces of planation in the Hungarian mountains and their relevance to pedimentation. In: M. Pécsi (Ed.), Problems of relief planation. Studies in Geography in Hungary. Akadémiai Kiadó, Budapest, pp. 29-40.

Perrodon, A., Zabek, J., 1990. Paris Basin. In: Leighton, M.W., Kolata, D.R., Oltz, D.F., Eidel, J.J. (Eds.), Interior cratonic basins. American Association of Petroleum Geologists Memoir. American Association of Petroleum Geologists, Tulsa, OK, pp. 633-679.

Peulvast, J.-P., Claudino Sales, V., 2005. Surfaces d'aplanissement et géodynamique. Géomorphologie: relief, processus, environnement 4, 249-274.

Pinczés, Z., 1970. Planated surfaces and pediments of the Bükk mountains. In: M. Pécsi (Ed.), Problems of relief planation. Studies in Geography in Hungary. Akadémiai Kiadó, Budapest, pp. 55-63.

Plusquellec, Y., Rolet, J., Darboux, J.-R., with inputs from Bosold, A., Chantraine, J., Chauris, L., Chauvel, J.-J., Hallégouët, B., Le Goffic, M., Lulzac, Y., Mélou, M., Mulot, B., Pelhate, A., Thonon, P., 1999. Notice explicative, Carte géologique de France (scale 1:50,000), feuille Châteaulin (310). BRGM, Orléans, France, 162 p. Geological map by Plusquellec, Y., Rolet, J., Darboux, J.-R.

Poncet, J., 1961. Un témoin de Cénomanien dans la région de Lessay (Manche). Compte Rendu sommaire de la Société géologique de France 8, 121-121.

Quesnel, F., 2003. Paleoweathering and paleosurfaces from northern and eastern France to Belgium and Luxembourg: geometry, dating and geodynamic implications. Géologie de la France 1, 95-104.

Quesnel, F., Dupuis, C., Yans, J., Ricordel-Prognon, C., Rad, S., Storme, J.-Y., Barbier, F., Roche, E., Bourdillon, C., Smith, T., lacumin, P., 2009b. Reconstructing the Late Paleocene-Early Eocene continental paleosurface in and around the Paris and adjacent basins: new insights for paleogeographic, geodynamic and climatic studies, Climatic and Biotic Events of the 
Paleogene (CBEP 2009). GNS Science Miscellanous series, Wellington, New Zealand, pp. 102106.

Quesnel, F., Prost, A.E., Lablanche, G., Thiry, M., Simon-Coincon, R., Théveniaut, H., Maget, P., Barbarand, J., Cribellier, C., 2009a. Notice explicative, Carte géologique de France (scale 1:50,000), feuille Châteaumeillant (595). BRGM, Orléans, France, 139 p. Geological map by Quesnel, F., Prost, A.E., Lablanche, G., Thiry, M., Simon-Coinçon, R., 2005.

Ramsay, A.C., 1846. On the Denudation of South Wales and the Adjacent Counties of England. Memoir of the Geological Survey of Great Britain, 1, 297-335.

Ricordel, C., 2007. Datations par paléomagnétisme des paléoaltérations du Massif Central et de ses bordures : implications géodynamiques. PhD thesis, Ecole Nationale Supérieure des Mines de Paris., France, 184 pp.

Ricordel, C., Parcerisa, D., Thiry, M., Moreau, M.G., Gomez-Gras, D., 2007. Triassic magnetic overprints related to albitization in granites from the Morvan Massif (France). Palaeogeography, Palaeoclimatology, Palaeoecology 251, 268-282.

Ricordel-Prognon, C., Lagroix, F., Moreau, M.-G., Thiry, M., 2010. Lateritic paleoweathering profiles in French Massif Central; paleomagnetic datings. Journal of Geophysical Research, 115, B10104, doi:10.1029/2010JB007419.

Rioult, M., 1968. Contribution a l'étude du Lias de la bordure occidentale du bassin de Paris (Normandie-Maine). Thèse de Doctorat d'Etat, Université de Caen, France, 565 pp.

Rioult, M., Pellerin, J., Juignet, P., 1966. Témoins résiduels d'Albien en Basse-Normandie et spécialement sur la campagne de Caen. Bulletin de la Société Linéenne de Normandie 10, 19-44.

Roche, E., Dupuis, C., Stambouli-Essassi, S., Russo-Ermolli, E., De Putter, T., Nicaise, D., FaironDemaret, M., 2008. Phytostratigraphie et paléoenvironnements du Néogène de l'EntreSambre-et-Meuse et du Condroz (Belgique). Evolution paléoclimatique du subtropical humide au tempéré froid. Geo-Eco-Trop 32, 101-130.

Rosenkranz, E., 1970. Pediments on the northeastern border of the Thuringian Forest. In: Pécsi, M.(Ed.), Problems of relief planation. Studies in Geography in Hungary. Akadémiai Kiadó, Budapest, pp. 133-136.

Ruffell, A.H., 1995. Evolution and hydrocarbon prospectivity of the Brittany Basin (Western Approaches Trough), offshore north-west France. Marine and Petroleum Geology 12, 387407.

Schmitt, J.M., Simon-Coincon, R., 1985. La paléosurface infra-liasique en Rouergue; dépôts sédimentaires et altérations associées. Géologie de la France 2, 125-135.

Sellier, D., 1985. Les versants du pays natais. Etude géomorphologique. PhD thesis, Université de Nantes, 506 pp.

Siddall, R., 1993. Thermotectonic evolution of the continental margins of the Bay of Biscay: application of apatite fission track analysis. PhD thesis (unpubl.), University of London.

Smith, M.J., Pain, C.F., 2011. Geomorphological Mapping. In: Gregory, K.J., Goudie, A.S. (Eds.), The SAGE handbook of Geomorphology. SAGE Publications, London, pp. 142-153.

Steinberg, M., 1967. Contribution à l'étude des formations continentales du Poitou. PhD thesis, Université de Paris XI (Orsay), 415 pp.

Strudley, M.W., Murray, A.B., Haff, P.K., 2006. Emergence of pediments, tors, and piedmont junctions from a bedrock weathering-regolith thickness feedback. Geology 34, 805-808.

Tator, B.A., 1952. Pediment characteristics and terminology; Part 1, Pediment characteristics. Annals of the Association of American Geographers 42, 295-317.

Tator, B.A., 1953. Pediment characteristics and terminology; Part 2, Terminology. Annals of the Association of American Geographers 43, 47-53.

Théveniaut, H., Quesnel, F., Wyns, R., Hugues, G., 2007. Palaeomagnetic dating of the "Borne de Fer" ferricrete (NE France): Lower Cretaceous continental weathering. Palaeogeography, Palaeoclimatology, Palaeoecology 253, 271-279. 
Thinon, I., Fidalgo-Gonzalez, L., Rehault, J.-P., Olivet, J.-L., 2001. Déformations pyrénéennes dans le golfe de Gascogne. Comptes Rendus de l'Académie des Sciences, Série II 332, 561-568.

Thinon, I., Matias, L., Réhault, J.-P., Hirn, A., Fidalgo-González, L., Avedik, F., 2003. Deep structure of the Armorican Basin (Bay of Biscay): a review of Norgasis seismic reflection and refraction data. Journal of the Geological Society, London 160, 99-116.

Thinon, I., Menier, D., Guennoc, P., Proust, J.-N., with inputs from Guillocheau, F., Bonnet, S., Le Roy, P., Augris, C., Bourillet, J.-F., Baltzer, A., Tessier, B., Pastol, Y., Garlan, T., Béchennec, F., Le Métour, J., Graviou, P., Alix, A.-S., Cornu, S., Loget, N., Renault, M., Scalliet, F., 2009. Carte géologique de la France à 1:250,000: Marge continentale-Lorient, Bretagne Sud. France. BRGM-CNRS.

Thiry, M., 1988. Les grés lustrés de l'Eocène du Bassin de Paris; des silcrètes pédologiques. Bulletin d'Information des Géologues du Bassin de Paris 25, 15-24.

Thiry, M., 1997. Continental silicifications; a review. In: Paquet, H., Clauer, N. (Eds.), Soils and Sediments. Springer, Berlin, pp. 191-221.

Thiry, M., 1999. Diversity of continental silicification features; examples from the Cenozoic deposits in the Paris Basin and neighbouring basement. In: Thiry, M. (Ed.), Palaeoweathering, palaeosurfaces and related continental deposits. Special Publication of the International Association of Sedimentologists 27, pp. 87-127.

Thiry, M., Delaunay, A., Dewolf, Y., Dupuis, C., Ménillet, F., Pellerin, J., Rasplus, L., 1983. Les périodes de silicification au Cénozoïque dans le Bassin de Paris. Bulletin de la Société Géologique de France 25, 31-40.

Thiry, M., Bertrand Ayrault, M., Grisoni, J.C., Ménillet, F., Schmitt, J.M., 1988a. Les grés de Fontainebleau; silicifications de nappes liées à l'évolution géomorphologique du bassin de Paris durant le Plio-Quaternaire. Bulletin de la Société Géologique de France 4, 419-430.

Thiry, M., Koeniguer, J.C., Menillet, F., 1988b. Les silifications de surface; la typologie et les outils de leur interprétation. Bulletin d'Information des Géologues du Bassin de Paris 25, 5-14.

Thiry, M., Simon-Coinçon, R., Quesnel, F., Wyns, R., 2005. Altération bauxitique associée aux argiles à chailles sur la bordure sud-est du bassin de Paris. Bulletin de la Société Géologique de France 176, 199-214.

Thiry, M., Quesnel, F., Yans, J., Wyns, R., Vergari, A., Theveniaut, H., Simon-Coincon, R., Ricordel, C., Moreau, M.-G., Giot, D., Dupuis, C., Bruxelles, L., Barbarand, J., Baele, J.-M., 2006. Continental France and Belgium during the Early Cretaceous; paleoweatherings and paleolandforms. Bulletin de la Société Géologique de France 177, 155-175.

Thomas, M.F., 1989a. The role of etch processes in landform development; 1, Etching concepts and their applications. Zeitschrift für Geomorphologie 33, 129-142.

Thomas, M.F., 1989b. The role of etch processes in landform development; 2, Etching and the formation of relief. Zeitschrift für Geomorphologie 33, 257-274.

Twidale, C.R., 1997. The great age of some Australian landforms: examples of, and possible explanations for, landscape longevity. In: Widdowson, M. (Ed.), Palaeosurfaces: recognition, reconstruction and palaeoenvironmental interpretation. Geological Society of London, Special Publication, pp. 13-23.

Twidale, C.R., Bourne, J.A., 2013. Pediments as etch forms: implications for landscape evolution. Journal of Geology 121, 607-602.

Utescher, T., Mosbrugger, V., Ivanov, D., Dilcher, D.L., 2009. Present-day climatic equivalents of European Cenozoic climates. Earth and Planetary Science Letters 284, 544-552.

Vérague, J., 1974. La transgression cénomanienne et les témoins anté-cénomaniens d'altération entre Sées et Alençon (Orne). Norois 84, 541-562.

Vérague, J., 1977. Les altérations des roches du socle armoricain : relictes morpho-climatiques de la continentalisation post-hercynienne entre Sées et Alençon (Basse-Normandie). Norois 94, 251-269. 
Vergés, J., Millán, H., Roca, E., Muñoz, J.A., Marzo, M., Cirés, J., Den Bezemer, T., Zoetemeijer, R., Cloetingh, S., 1995. Eastern Pyrenees and related foreland basins; pre-, syn- and postcollisional crustal-scale cross-sections. Marine and Petroleum Geology 12, 903-915.

Vernhet, Y., Doré, F., Lautridou, J.P., Talbo, H., Verron, G., Dhellemmes, R., Enouf, C., 1995. Notice explicative, Carte géologique de France (scale 1:50,000), feuille Domfront (249 BRGM, Orléans, France, 106 pp. Geological map by Vernhet, Y., Dhellemmes, R., Doré, F., Enouf, C., Lautridou, J. P., Verron, G., 1996.

Vernhet, Y., Chèvremont, P., Langevin, C., 1997. Notice explicative, Carte géologique de France (scale 1:50,000), feuille Landivy (248). BRGM, Orléans, France, 83 p. Geological map by Vernhet, Y., Chèvremont, with inputs from Lautridou, J.-P.

Vernhet, Y., Lerouge, G., Besombes, J.-C., Le Gall, J., Gigot, P., Cuney, M., Pivette, B., Lebret, P., Thiéblemont, D., 2009. Notice explicative, Carte géologique de la France (scale 1:50,000), feuille Mayenne (285). BRGM, Orléans, France, 225 pp. Geological map by Vernhet, Y., Lerouge, G., Besombes, J.-C., Le Gall, J., Gigot, P., Lebret, P. with inputs from Cousin, D., Coutin, C., Perrochain, C., Pirus, S., Rouillon, C., Sejalon, D., Souchal, C.

Vissers, R.L.M., Meijer, P.T., 2012a. Mesozoic rotation of Iberia: subduction in the Pyrenees? EarthScience Reviews 110, 93-110.

Vissers, R.L.M., Meijer, P.T., 2012b. Iberian plate kinematics and Alpine collision in the Pyrenees. Earth-Science Reviews 114, 61-83.

Warrington, G., Ivimey-Cook, H.C., 1992. Triassic. In: Cope, J.C.W., Ingham, J.K., Rawson, P.F. (Eds.), Atlas of palaeogeography and lithofacies. Geological Society of London Memoir, pp. 97-106.

Weiss, A.D., 2001. Topographic Position and Landforms Analysis. Poster presentation, ESRI Users Conference, San Diego, CA.

Whitaker, C.R., 1979. The use of the term 'pediment' and related terminology. Zeitschrift für Geomorphologie 23, 427-439.

White, K., 2004. Pediment. In: Goudie, A.S. (Ed.), Encyclopedia of Geomorphology. Routledge, London and New-York, pp. 768-771.

Wooldridge, S.W., Linton, D.L., 1955. Structure, surface and drainage in southeast England (2nd edn). George Philip and Sons Ltd., London, 176 pp.

Widdowson, M. 1997. The geomorphological and geological importance of palaeosurfaces. In: Widdowson, M. (ed.), Palaeosurfaces: recognition, reconstruction and palaeoenvironmental interpretation. Geological Society of London, Special Publications, 120, pp. 1-12.

Wyns, R., 1991. Evolution tectonique du bâti armoricain oriental au Cénozoïque d'aprés l'analyse des paléosurfaces continentales et des formations géologiques associées. Géologie de la France 3, 11-42.

Wyns, R., Quesnel, F., Simon-Coincon, R., Guillocheau, F., Lacquement, F., 2003. Major weathering in France related to lithospheric deformation. Géologie de la France 2003 1, 79-87.

Xu, C., Mansy, J.-L., Van Den Haute, P., Guillot, F., Zhou, Z., Chen, J., De Grave, J., 2009. Late- and post-Variscan evolution of the Ardennes in France and Belgium: constraints from apatite fission-track data. Geological Society of London, Special Publications 324, 167-179.

Yans, J., 2003. Chronologie des sédiments kaoliniques faciès wealiens (Barrémien moyen-Albien supérieur ; bassin de Mons) et de la saprolite polyphasée (Crétacé inférieur et Miocène inférieur) de la Haute-Lesse (Belgique). Implications géodynamiques et paléoclimatiques. PhD thesis, Faculté Polytechnique de Mons and Université de Paris-Sud Orsay, 316 pp.

Yans, J., with inputs from Chauvin, A., Dejax, J., de Putter, T., Dupuis, C., Feraud, G., Guillocheau, F., Masure, E., Leost, I., Perruchot, A., Pons, D., Spagna, P., Wyns, R., 2003. An overview of the saprolites of Belgium and their potential kaolinitic supplies to Mesozoic and Cainozoic sediments. Géologie de la France 1, 33-37.

Yans, J., Dupuis, C., 2007. Dating of the weathering processes in the Ardennes (Belgium). Geologica Belgica 10, 222-222. 
Yao, K., Thiry, M., Szuszkiewicz, A., Turniak, K., 2010. Petrological characterization of the Triassic palaeosurface in the northern Bohemian Massif. Geophysical Research Abstracts 12, EGU2010-7980.

Zachos, J.C., Pagani, M., Sloan, L., Thomas, E., Billups, K., 2001. Trends, rhythms, and aberrations in global climate $65 \mathrm{Ma}$ to present. Science 292, 686-693.

Zachos, J.C., Dickens, G.R., Zeebe, R.E., 2008. An early Cenozoic perspective on greenhouse warming and carbon-cycle dynamics. Nature 451, 279-283.

Ziegler, P.A., 1987. Evolution of the Western Approaches Trough. Tectonophysics 137, 341-346.

Ziegler, P.A., 1990. Geological atlas of Western and Central Europe, 1. Shell Internationale Petroleum Maatschappij B.V., The Hague, Netherlands, 239 pp. 


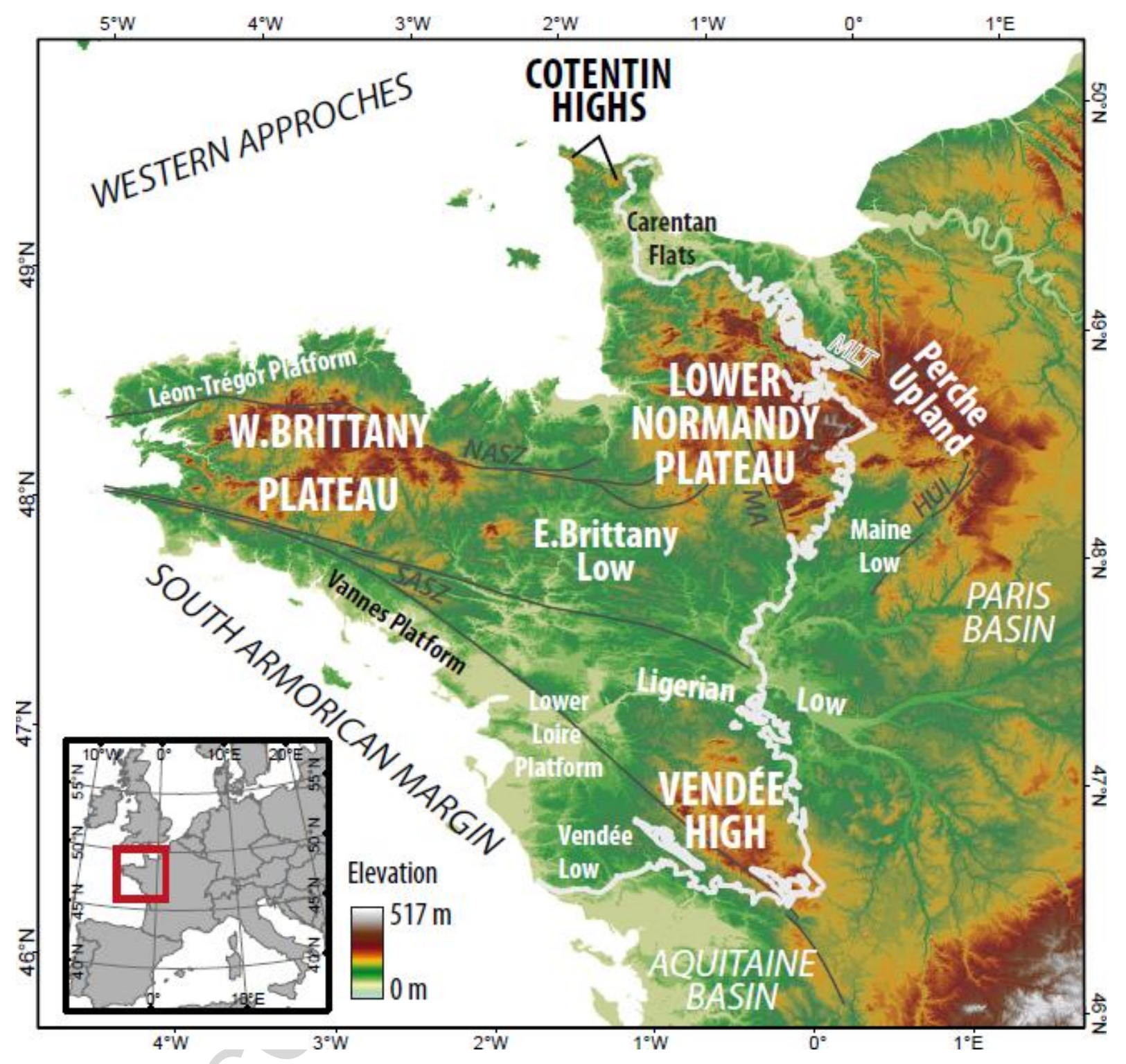

Figure 1 


\section{A}

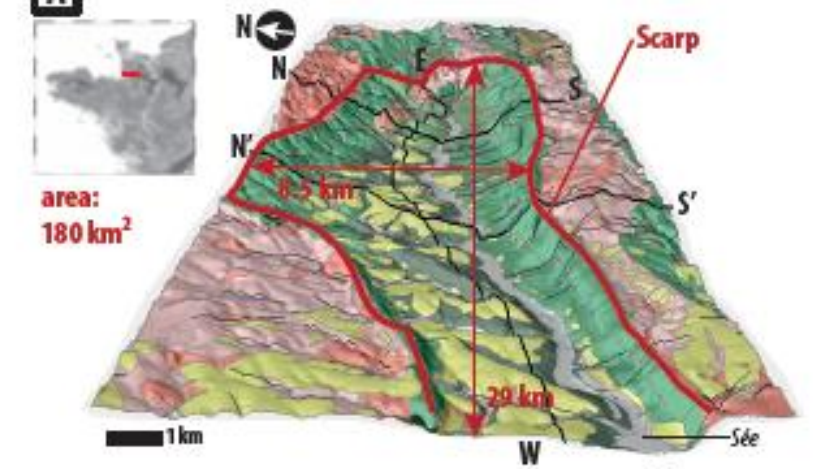

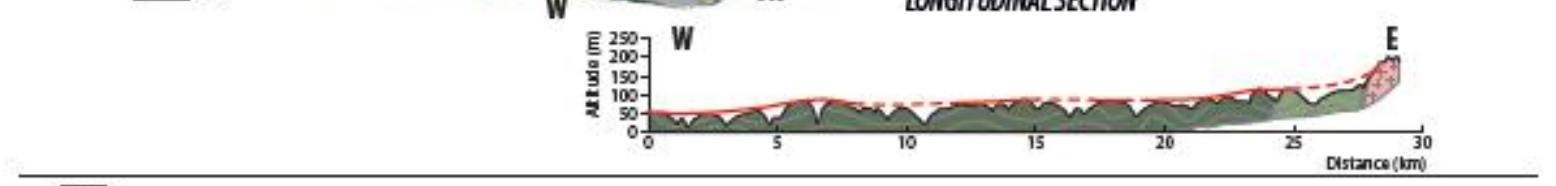

\section{IRANSVERSESECTIONS}
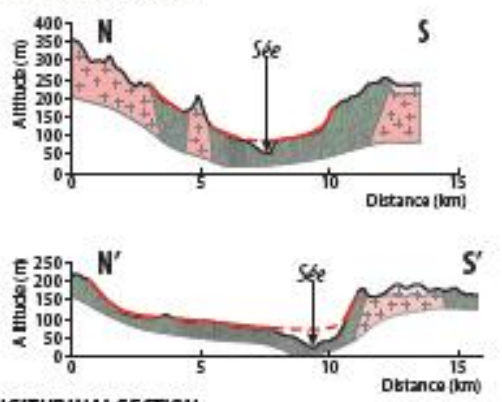

LONGITUDINALSECTION

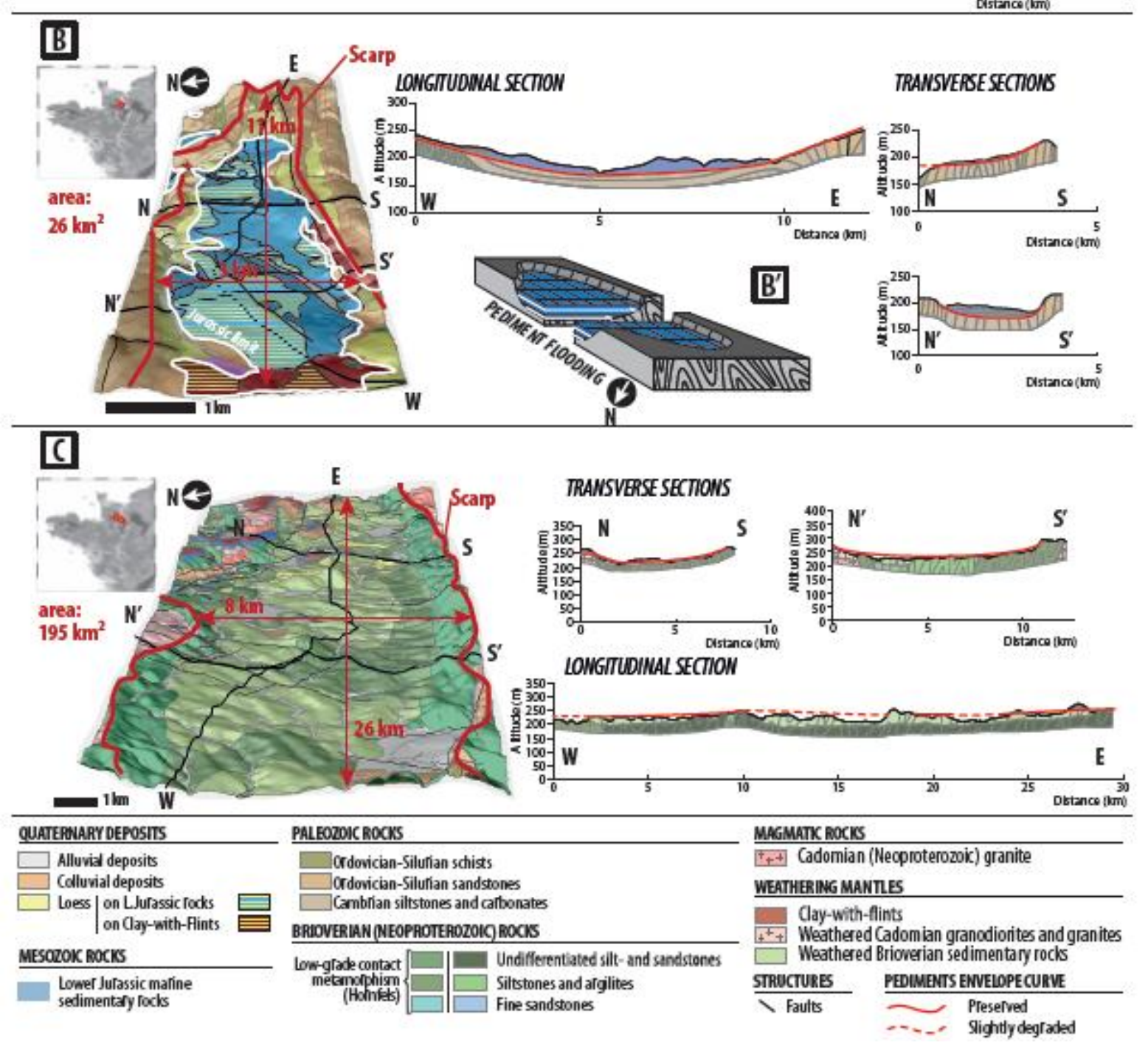

Figure 2 


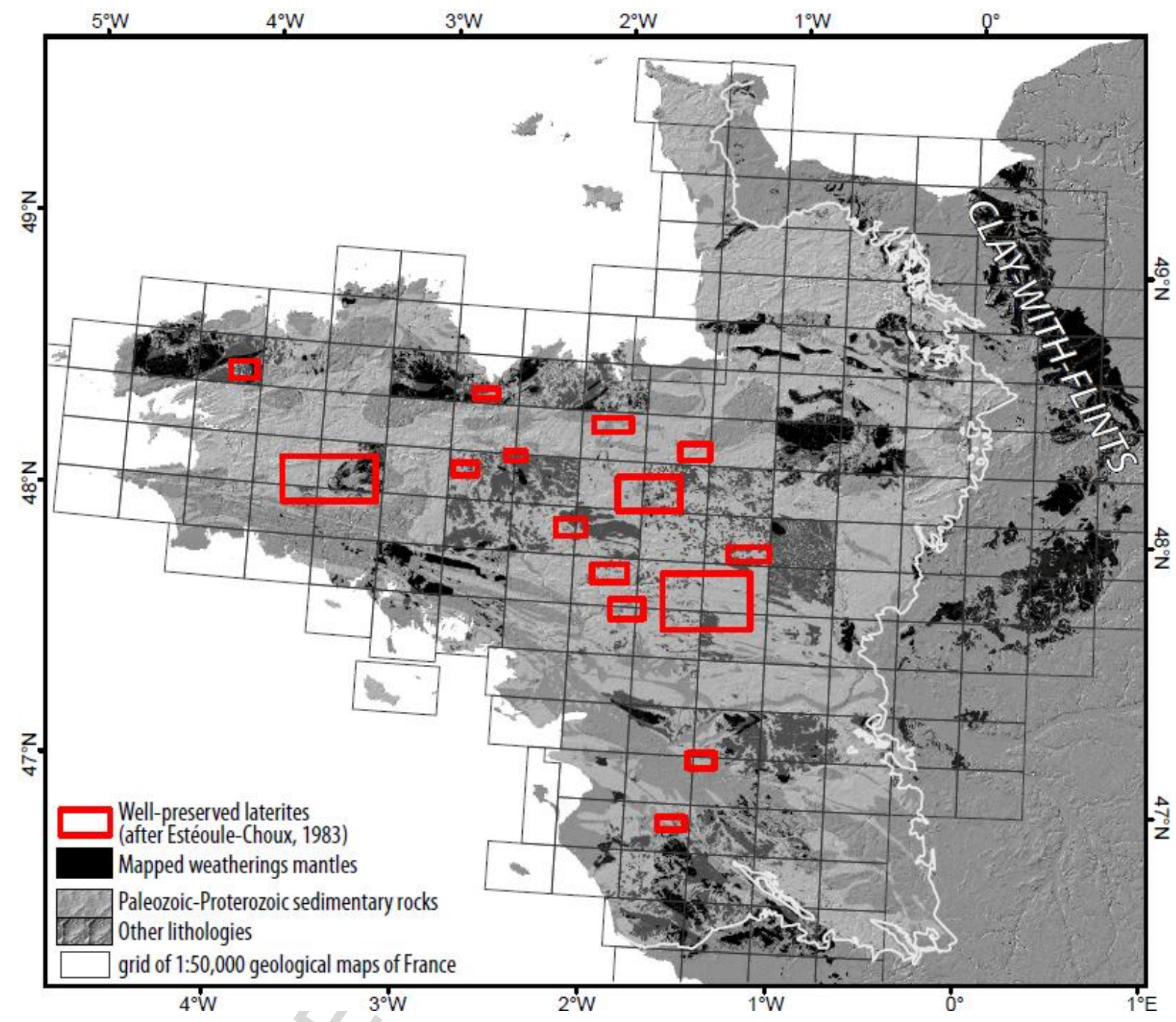

Figure 3 


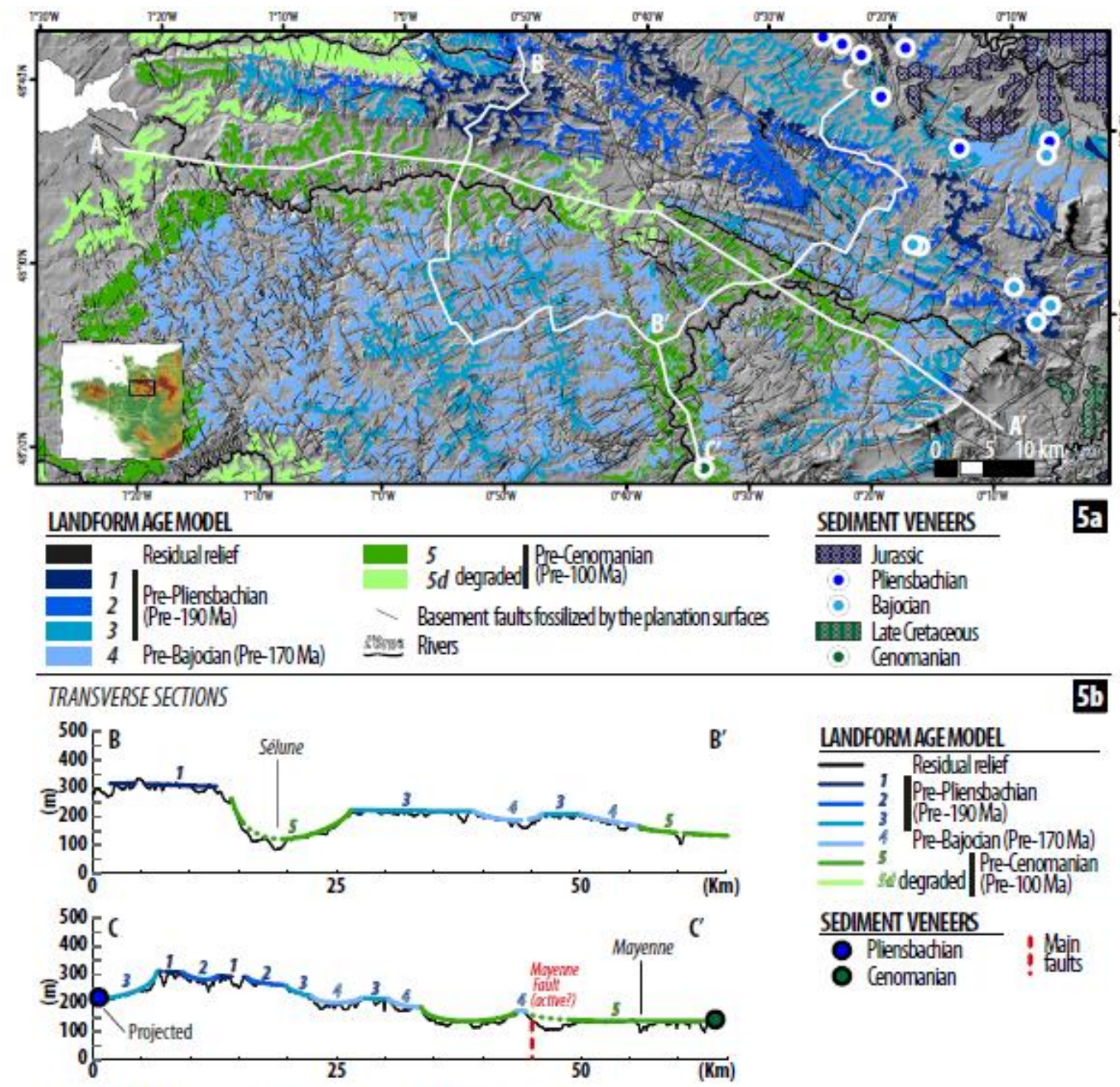

LONGITUDINAL SECTION OF THE MAYENNE-SELUNE PEDIMENT-VALLEY

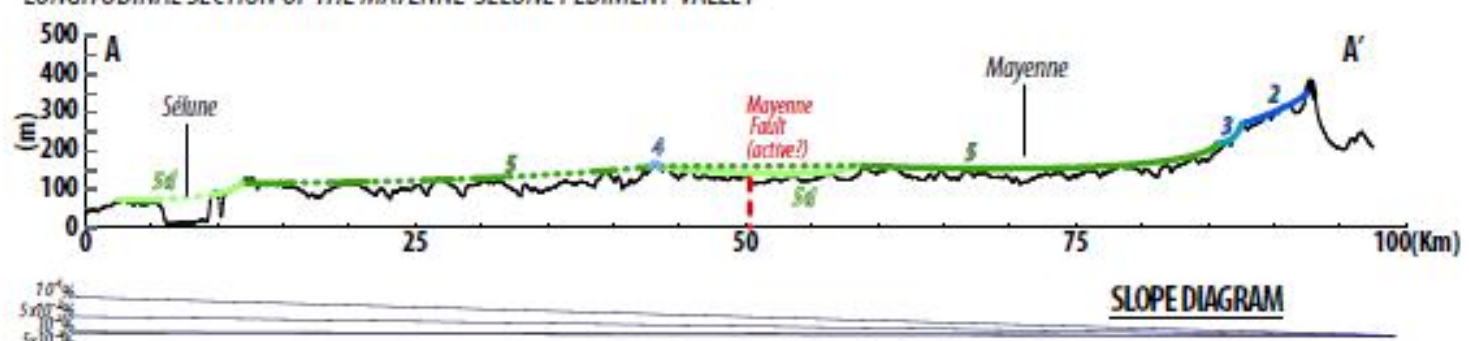

Figure 4 


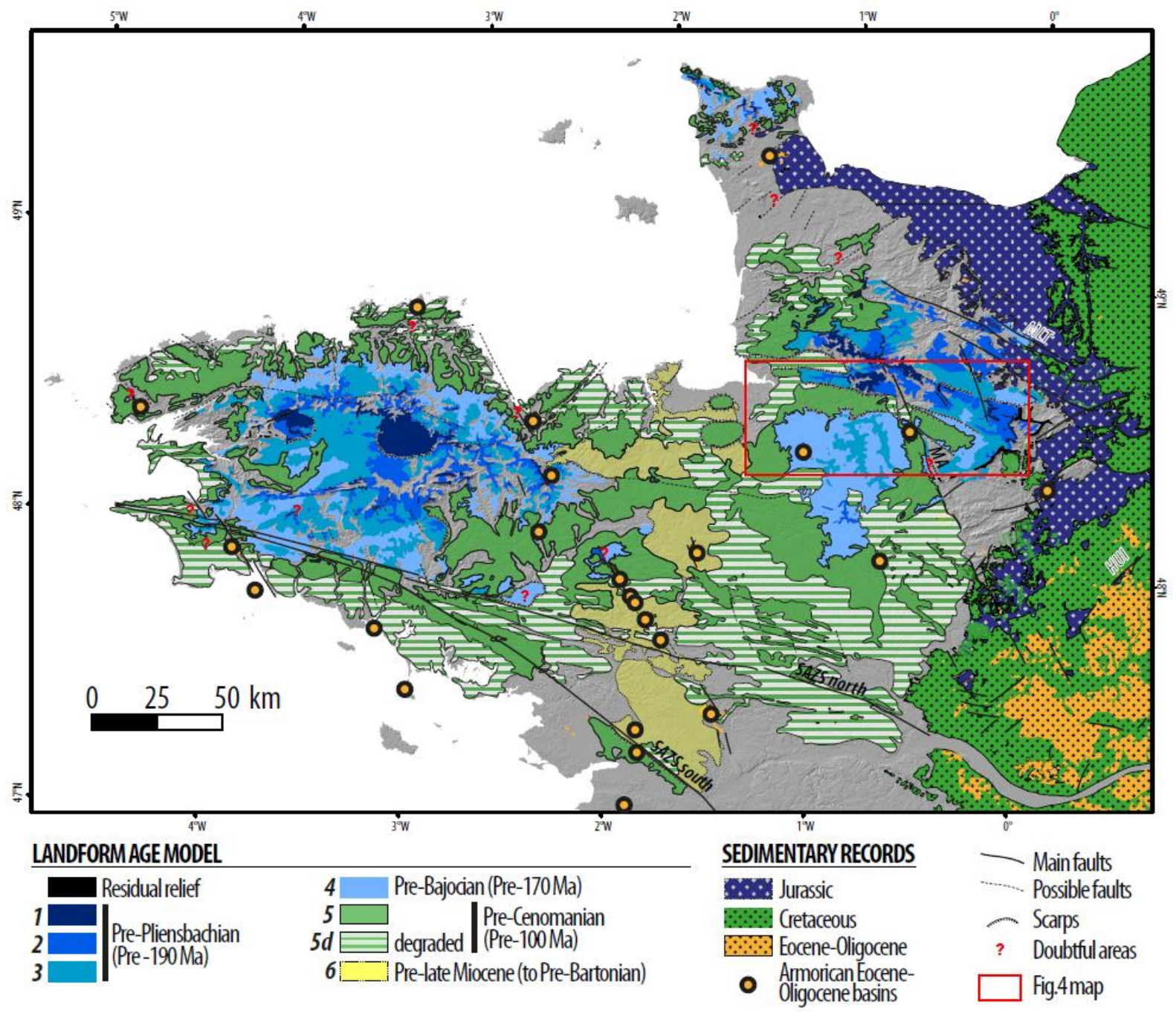

Figure 5 


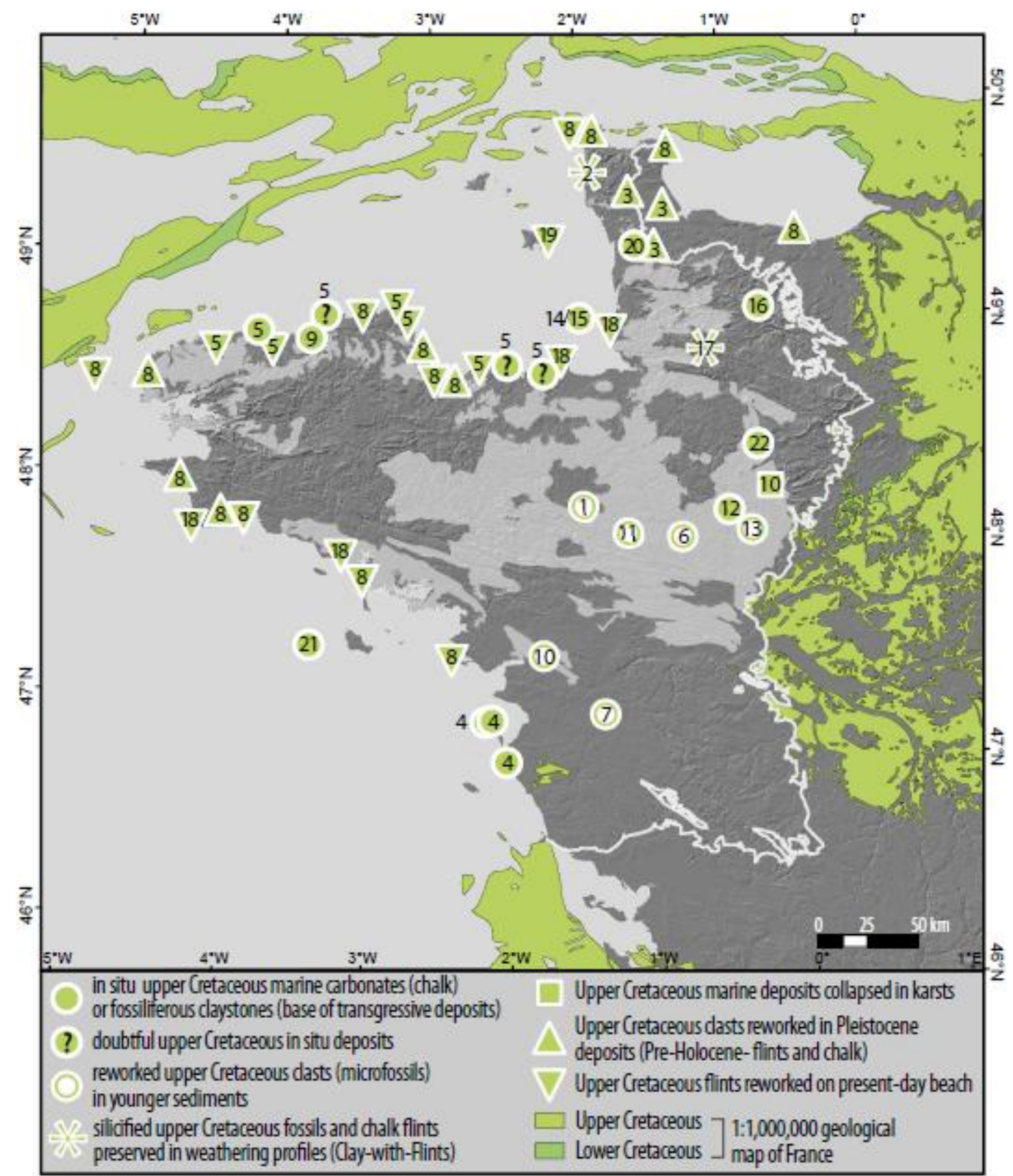

Figure 6 


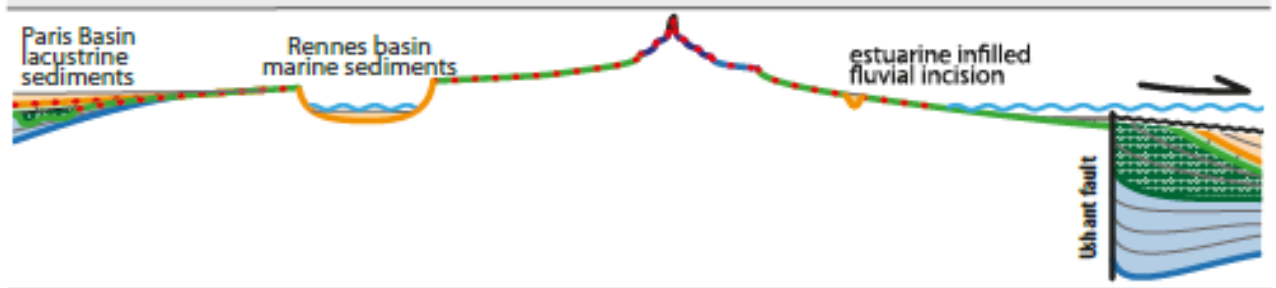

LOWER EOCENE: SECOND EXHUMATION-PEDIPLANATION/LATERIZATION
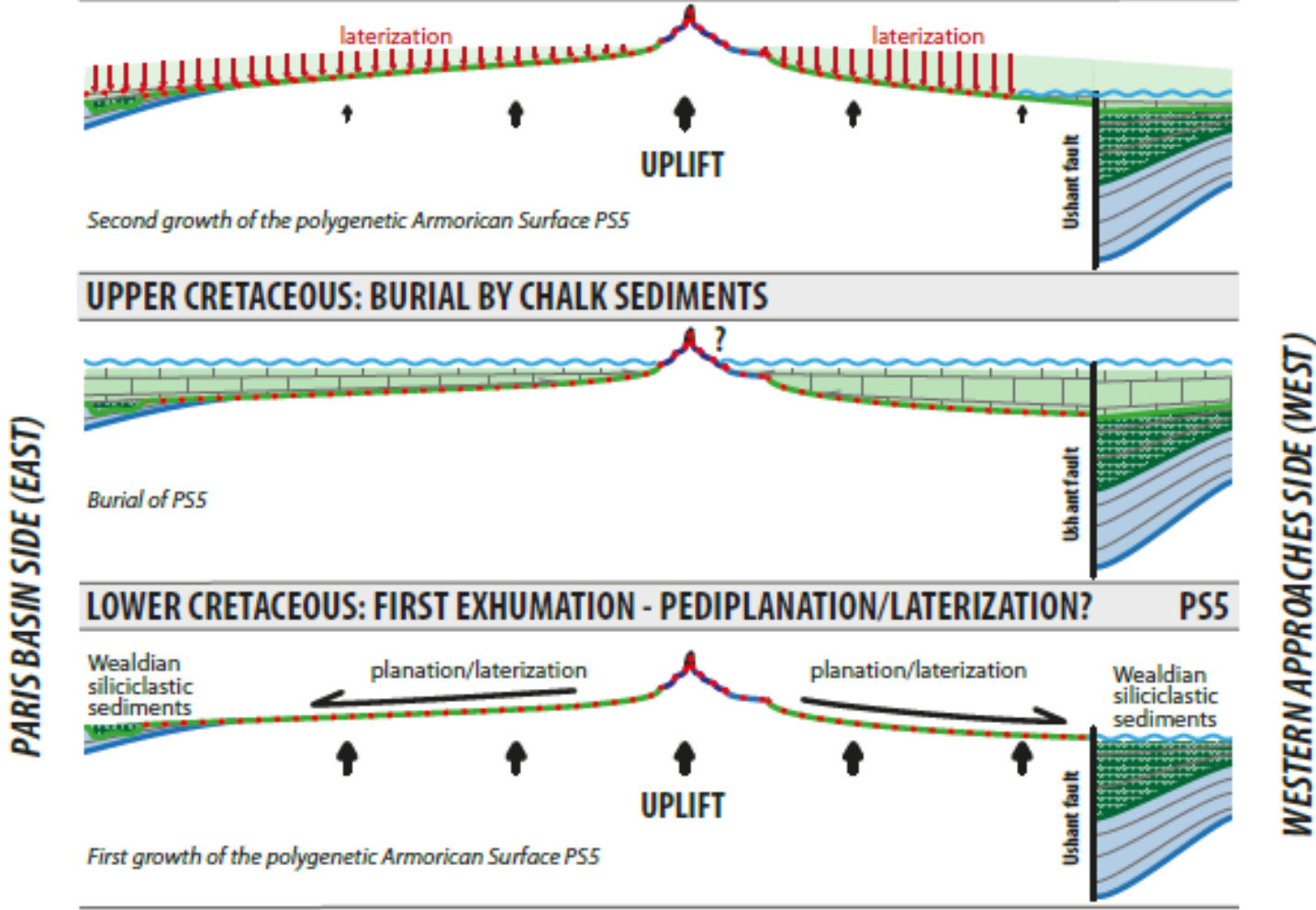

MIDDLE TO UPPER JURASSIC: BURIAL BY CARBONATE SEDIMENTS

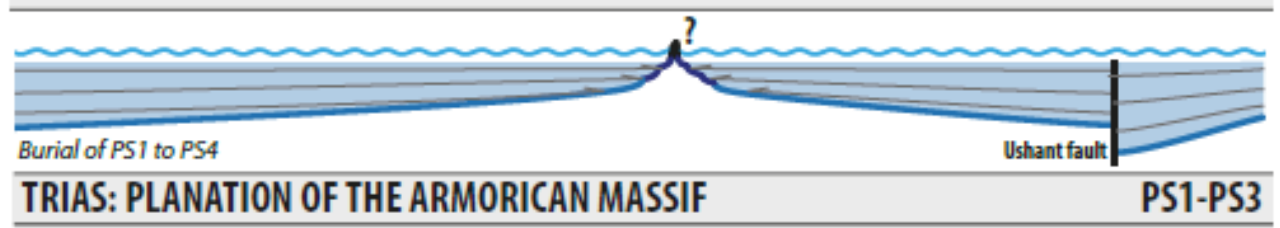

Triassic siliciclastic
sediments

Figure 7 
Highlights :

- We mapped and dated 6 stepped planation surfaces in Brittany, W. France

- 5 of these surfaces are Mesozoic (pre-late Cretaceous)

- They underwent two cycles of burial by cover rocks followed by exhumation

- We propose a long-term landscape evolution model of the Armorican Massif 